\title{
La responsabilidad del Estado en Argentina: breve comentario a su régimen legal
}

\author{
State responsibility in Argentina: \\ a briefcomment to its legal regime
}

\begin{abstract}
Resumen
En el presente texto se expondrán los antecedentes doctrinarios y jurisprudenciales sobre la responsabilidad estatal en Argentina, a partir del papel fundamental de la jurisprudencia en la construcción de la responsabilidad del Estado. Se revisa en el marco del dictado de la Ley 26.944 Congreso Nacional, la regulación de la responsabilidad estatal en el análisis de su articulado.
\end{abstract}

Palabras clave: Responsbilidad del Estado, Congreso Nacional, jurisprudencia.

\begin{abstract}
In the present text doctrinaire and jurisprudential background on state responsibility in Argentina will be presented, from the fundamental role of law in the construction of state responsibility. It is reviewed under the provisions of Law 26,944 National Congress, the regulation of state responsibility in the analysis of its articles.
\end{abstract}

Keywords: Accountability State, National Congress jurisprudence.

Résumé

Dans le présent doctrinaire de texte et le fond jurisprudentielle sur la responsabilité de l'Etat en Argentine sera présenté, du rôle fondamental du droit dans la construction de la responsabilité de l'État. Il est examiné en vertu des dispositions de la loi 26944 Congrès national, la réglementation de la responsabilité de l'État dans l'analyse de ses articles.

Mots-clés: État responsabilisation, la jurisprudence du Congrès national. 



\section{La responsabilidad del Estado en Argentina: breve comentario a su régimen legal}

Carlos Marcelo Lamoglia

\section{LOS PRIMEROS ANTECEDENTES DOCTRINARIOS Y JURISPRUDENCIALES SOBRE LA RESPONSABILIDAD ESTATAL EN ARGENTINA}

La teoría de la responsabilidad en el campo del derecho público, puntualiza Manuel María Diez: "tiene una gran importancia, desde que representa la posibilidad para el administrado de obtener reparación de los daños imputables al Estado" y es una "pieza esencial del Estado de derecho y toda teoría de la responsabilidad refleja una cierta forma de civilización" (1971, p. 18)1.

La doctrina argentina ha puntualizado que la razón o justificativo que brinda andarivel a la obligación de resarcir nace del propio texto de la Constitución Nacional, de los principios que nutren el Preámbulo y de aquellos que sostienen el mismo ordenamiento jurídico (v. gr. no dañar a otro, dar a cada uno lo suyo) ${ }^{2}$; de tal forma, se verifica la materialización de principios constitucionales como el vinculado a una tutela judicial efectiva y consolidándose de tal forma un sistema de responsabilidad complejo y eficaz; se buscaba así un sistema integral que tratará de cubrir las lesiones o daños producidos por todo tipo de actividad o inactividad administrativa -lícita o

Tratado de Derecho Administrativo, Tomo V, Editorial Plus Ultra, Buenos Aires, 1971, p. 18

2 Marienhoff, Miguel S. Tratado de Derecho Administrativo, 6ta ed. Actualizada. Abeledo -Perrot. Bs.As. 1997, $\mathrm{t}^{\circ}$ IV, ps. 724 a 727. Tal postura será seguida, afirma Mertehikian, por Bartolomé Fiorini, Rodolfo Bullrich y el mismo autor, en "La responsabilidad pública. Análisis de la doctrina y la jurisprudencia de la Corte Suprema”, Ed. Ábaco de Rodolfo Depalma, 1998, pág. 46 y 55. Se ha expedido en este sentido recientemente el Dr. Alberto Ricardo Dalla Vía, en "Aspectos constitucionales del Proyecto de Código Civil y Comercial", Rev. LL 2014-B-913; Manuel María Diez, ob. cit, pág. 55 quien expresa "Puede decirse, entonces, que la Constitución nacional proporciona un fundamento jurídico para declarar la responsabilidad del Estado, toda vez que la actividad de algunos de sus órganos causa un perjuicio especial a un habitante de la nación, en violación que la misma Constitución consagra en sus artículos 14 a 20. Esta responsabilidad existe, como dijimos, sea que los agentes actúen con o sin culpa y aunque la misma surja de un acto legítimo, porque su antijuridicidad en este supuesto arrancaría de su conflicto con la Constitución". 
ilícita- que los particulares no deban jurídicamente soportar (Hutchinson y Peirone, 2000, pp. 295 y ss; Rosatti s.f., pp. 73-89) ${ }^{3}$.

El Estado responsable logra su reconocimiento, en forma expresa, en distintos textos constitucionales; en el orden latinoamericano podemos citar al de Colombia ${ }^{4}$, México $^{5}$, Brasil (Art. 5 y 37 de la Constitución de Brasil), Chile (Art. 38, $2^{\circ}$ párrafo de la Constitución Chilena), Ecuador (Art. 9 de la Constitución de Ecuador); las constituciones de tales países insertan regulaciones precisas sobre la obligación de reparar del Estado en supuestos como los que hoy contiene la legislación en comentario; de igual forma la Unión Europea ${ }^{6}$.

Valiosos trabajos doctrinarios fueron contribuyendo positivamente en la formación de las directrices que hoy forman parte del Instituto Jurídico en nuestro país (Reiriz. 1969; Marienhoff, 1987; Cassagne, 1986; Altamira, 1973) 7 , hasta la reciente sanción de la Ley No. 26.944 (B.O. 8 de agosto de 2014). En Argentina, al dejar de lado la vieja doctrina de la irresponsabilidad del Estado, se reconoció como un principio básico del Estado de derecho la reparación los perjuicios ocasionados por el Estado, pues los sujetos afectados no tienen la obligación de soportar los mismos aun cuando los genere una entidad pública.

El reconocimiento de un Estado responsable vino acompañado -casi inevitablemente - con la idea del Estado demandable (Ley 3952 del 27 de septiembre de 1900), resultando inescindible tales conceptos.

3 Tomas Hutchinson y Silvia Peirone, "Estudio preliminar sobre la responsabilidad del Estado por su actividad Tributaria” en Revista de Daños Nro. 9 Ed. Rubinzal Culzoni Editores, pág. 295 y ss. 2000, Rosatti Horacio Daniel "La responsabilidad extracontractual del Estado en base a normas del Código Civil: una crítica”. Revista de Derecho de Daños, 9. Ed. Rubinzal Culzoni, p. 73, en especial p. 89.

4 Art. 90 de la Constitución de Colombia -Texto 1991- "El Estado responderá patrimonialmente por los daños antijurídicos que le sean imputables, causados por la acción o la omisión de las autoridades públicas. En el evento de ser condenado el Estado a la reparación patrimonial de uno de tales daños, que haya sido consecuencia de la conducta dolosa o gravemente culposa de un agente suyo, aquel deberá repetir contra éste".

5 Art. 113, 2․ Párrafo, de la Constitución Política de los Estados Unidos Mexicanos "La responsabilidad del Estado por los daños que, con motivo de su actividad administrativa irregular, cause en los bienes o derechos de los particulares, será objetiva y directa. Los particulares tendrán derecho a una indemnización conforme a las bases, límites y procedimientos que establezcan las leyes.

6 El artículo 340 del Tratado de Funcionamiento de la Unión Europea, en su segundo párrafo reconoce la responsabilidad extracontractual de la Unión por los daños causados por sus instituciones o sus agentes en el ejercicio de sus funciones, de conformidad con los principios generales comunes a los Derechos de los Estados miembros. Para exigir esa responsabilidad, el tratado prevé una acción procesal, un recurso, cuya competencia, por el artículo 268 del tratado mencionado, atribuye al Tribunal de Justicia de la Unión Europea (Jesús Ángel Fuentes Pastor. En Derecho Administrativo Europeo. Civitas - Thomson Reuters, Editorial Aranzadi, S.A., Madrid, $1^{a}$ edición, 2014, p. 441).

7 Reiriz, María Graciela. La Responsabilidad del Estado. Bs.As., 1969; Marienhoff, Miguel. Tratado de Derecho Administrativo, t. IV, pp. 97 y ss. Bs.As. 1987; Hutchinson, Tomas. Los daños producidos por el Estado. Rev. JUS, 36, 194; Juan Carlos Cassagne. Derecho Administrativo, t. I, p. 265, Bs. As. 1986; Altamira Gigena. Responsabilidad del Estado. Bs. As. 1973; Pablo E. Perrino. La Responsabilidad de la Administración por su actividad ilícita. Revista. ED, t. 185- 781, entre otros. 


\section{EL PAPEL FUNDAMENTAL DE LA JURISPRUDENCIA EN LA CONSTRUCCIÓN DE LA RESPONSABILIDAD DEL ESTADO}

En Argentina por el año 1933, con el caso "Devoto", admite la doctrina9 se logra fortalecer el reconocimiento del instituto en ámbito del derecho público argentino, si bien en aquella oportunidad utilizando normas y principios del derecho privado para justificar la obligación de responder por parte del Estado.

El mismo tribunal de justicia, siguiendo ésta senda, dicta sentencia en la causa "Ferrocarril Oeste de Buenos Aires c/ Provincia de Buenos Aires s/ indemnización de daños y perjuicios" (Fallos 182:5 del 3/10/1938), revistiendo el mismo suma importancia, toda vez que el fundamento que brindó para responsabilizar al Estado fue la figura de la "falta de servicio". Una laboriosa actividad de la Corte Suprema de Justicia de la Nación, conjuntamente con la doctrina especializada, fue consolidando la responsabilidad estatal, delineando los requisitos sustanciales de la institución ${ }^{10}$, como los distintos supuestos que ella abarca (ilícita, licita, omisión, entre otras) ${ }^{11}$.

Corresponde recordar, en esta pincelada de la jurisprudencia del Tribunal cimero del país, lo resuelto en las causas "Vadell, Jorge (Fallos 306:2030; en LL.1985-B-3)" y "Barreto, Alberto 12"; no solo por continuar la ruta marcada por los anteriores, sino por generar una doctrina que fortaleció el Instituto en estudio y además contribuyó a la autonomía misma del derecho administrativo argentino ${ }^{13}$.

8 CSJN del 22/09/1933, Fallos 169:111 y J.A., Tomo 43, con nota del doctor Rafael Bielsa titulada "Responsabilidad del Estado como poder administrador".

9 Carlos Colautti. Responsabilidad del Estado. Problemas constitucionales. Rubinzal Culzoni Editores, 2003, p. 53 quien califica al precedente como el "caso clásico que implicó un cambio fundamental en la jurisprudencia, y el punto de evolución hacia la actual jurisprudencia”.

10 Tal como lo puntualiza la doctrina, el sistema de responsabilidad estatal ha sido de origen jurisprudencial. Fabián Canda. "La responsabilidad del Estado se rige por el derecho administrativo. El derecho administrativo es esencialmente local. La responsabilidad del Estado es asunto de derecho público local”. En Máximos Precedentes. Director Juan Carlos Cassagne, Ed. La Ley 2013, p.633. citando a Pablo Perrino E. La responsabilidad extracontractual del Estado por actividad ilicita en el Derecho argentino.

11 Sobre la evolución jurisprudencial: Eduardo Mertehikian. La responsabilidad pública. Análisis de la doctrina y la jurisprudencia de la Corte Suprema. Ed. Ábaco de Rodolfo Depalma, 1998 y autores de nota 1. Sobre la evolución de la responsabilidad administrativa señala Manuel María Diez, "En el primer sistema el Estado era irresponsable. La irresponsabilidad del mismo se consideró, en la primera mitad del siglo XIX, como un corolario de la soberanía. Se sostenía en esa época que la existencia de una responsabilidad que quede a cargo de los patrimonios administrativos debe ser considerado como una carga enojosa para la libertad de los servicios públicos".

12 Fallos 329:759. En igual sentido, "Ledesma, Luis", del 11/7/2006; Fallos 332:548 donde se remite al dictamen de la Procuración General de la Corte, en el cual se reitera la exclusión del concepto de "causa civil" "a los casos de presunta "falta de servicio" por entender que es una materia propia del derecho público y su regulación corresponde al derecho administrativo, por lo que resultan del resorte exclusivo de los gobiernos locales".

13 Sarmiento García en su publicación "Responsabilidad del Estado. Principios y proyecto de ley" recuerda que Renato Alessi ha expresado que "el derecho administrativo, respecto a un determinado conjunto de relaciones (precisamente aquellas inherentes al desarrollo de la función administrativa) constituye él mismo un jus commune, es decir, un sistema jurídico autónomo, paralelo al derecho privado", del 11/03/14 (LL 2014-B). 
En el primero de ellos se consolida la responsabilidad del Estado extracontractual, pero esta vez sustentada en una concepción objetiva y directa, sobre la base de la "falta de servicio" que encuentra anclaje en el artículo 1112 del Código Civil ${ }^{14}$, al cual se recurrirá en forma subsidiaria o directa de acuerdo con la interpretación que se efectuara de la norma y su vinculación al derecho público.

Tal posición fue seguida por la propia jurisprudencia y logró recepción normativa en la actual ley, como también en los doctrinarios que redactaron el anteproyecto del Código Comercial que logró luego su sanción mediante la Ley $\mathrm{N}^{\circ} 26.994$, pero en lo que a la cuestión en estudio no logró su regulación en dicho texto, quedando diferida a una ley especial que atienda tal materia -vgr. La ley en comentario-.

En el fallo Barreto la Corte Suprema de Justicia de la Nación produce un aporte positivo a la controversia que luego resolverá el legislador con la sanción de la ley, al delimitar el concepto de "causa civil" cuando para la solución del pleito se remite a la aplicación de disposiciones de derecho común y, por lo tanto, no reviste tal categoría, la que pese a demandarse indemnizaciones con carácter civil, "se requiere para su solución la aplicación de normas de derecho público provincial o la revisión de actos estatales locales dados en ejercicio de las facultades que resultan del art. $122 \mathrm{CN} " 15$.

En la configuración y alcance de la responsabilidad estatal han existido distintas miradas; aquella proveniente del derecho privado que postula la regulación por las normas del Código Civil, al entender que tal temática se vincula a cuestiones del derecho de fondo -y por ende, corresponde a esta normativa-o, más específicamente, al derecho de daños ${ }^{16}$.

14 Se hace referencia al texto vigente al momento del presente trabajo, no obstante, advertirse que la norma civil en Argentina ha sido modificada mediante Ley 29.994 (B.O. 8/10/2014) con vigencia a partir del 1/8/2015.

15 Considerando $8^{\circ}$ del fallo, lo cual hace concluir a Canda que "para la Corte la responsabilidad del Estado es una materia propia del derecho público y, consecuentemente, es de naturaleza local, por lo que legislación y juzgamiento corresponde a las provincias y queda excluido del concepto de "causa civil" y de su competencia originaria", en la obra "Máximos...” ob.cit. pág. 639. Una interpretación contraria realiza Emilio Ibarlucia al sostener que "a la causa "Barreto" no debe dársele un alcance mayor que el que surge expresamente de sus considerandos: restringir el alcance del concepto de "causa civil" de forma tal de disminuir el número de causas tramitables en instancia originaria de la Corte, para que el alto tribunal pueda abocarse a su misión constitucional más importante, que es la que se origina en el recurso extraordinario federal", en "Responsabilidad del Estado y de los funcionarios públicos ¿Código Civil o Ley Provincial?, diario LL 2014-D-739.

16 Tal como lo ha mencionado Jorge Mosset Iturraspe, "no es exagerado sostener que los civilistas, cultores de esta especialidad, han sido, casi en su totalidad, partidarios de aplicar la normativa del Código Civil. Sin admitir, al menos como regla, que el Estado deba merecer "un trato especial", una consideración particular", en "Visión Jusprivatista de la responsabilidad del Estado", obra colectiva Responsabilidad del Estado y de los Funcionarios Públicos. Rubinzal Culzoni Editores, 2003, p. 19. El autor cita, entre otros, en la misma tesitura a los doctores Augusto Belluscio y Zannoni Eduardo; si bien reconoce que puede haber un régimen específico, diferenciado, para ciertas situaciones especiales, ello no modifica su postura en el sentido de que "el Código Civil, o el Código del Derecho Privado, hace de la "responsabilidad pública" del Estado y de la responsabilidad de los funcionarios o agentes públicos un "tema propio" donde las diferencias desaparecen y la asimilación con las personas jurídicas privadas y sus agentes o administradores apunta a ser completa”, p. 21. En este 
En tal contexto, se planteó la necesidad de estudiar el Instituto como una materia propia del derecho administrativo, y por ello sujeto a normas y principios de dicha rama del derecho. En esta postura, la legislación civil solo podría ser aplicable en la solución del caso en forma supletoria o analógica, pero donde deberían primar las construcciones ideadas y forjadas bajo el interés de la comunidad y al grado de contribución de sus miembros a las cargas y sacrificios que son necesarios para mantener el buen funcionamiento de los servicios que se prestan al ciudadano ${ }^{17}$.

Manuel María Diez, luego de realizar un estudio acerca de las disposiciones legales que se fueron aplicando para resolver los conflictos suscitados en este ámbito, reconocía que si bien durante un tiempo se regía por el Código Civil y que "la invocación de las normas del derecho civil significó, sin embargo, un progreso indudable frente al principio de irresponsabilidad estatal...", -testifica el tratadista"este régimen fue prontamente superado, afirmándose paulatinamente el criterio de que la responsabilidad de la administración debía regularse por principios del derecho público. Esta es la opinión dominante en la actualidad y técnicamente preferible en nuestra opinión"18.

\section{EL DICTADO DE LEY 26.944 POR EL CONGRESO NACIONAL}

Después de "Devoto" y habiendo transcurrido un periodo importante en el que la jurisprudencia -y la doctrina- aportaron elementos significativos para su regulación, el legislador nacional tomó la decisión de sancionar una ley sobre responsabilidad del Estado, que contiene y delinea los presupuestos, su ámbito de aplicación y demás pautas para arribar a una indemnización justa. De tal forma se ha buscado dar

sentido también puede citarse a la doctora Kemelmajer de Carlucci, Aída "La responsabilidad del Estado: enfoque jurídico-privado", AA.VV. La responsabilidad del Estado. UNSTA, Tucumán, 1982; quien concluía, luego de analizar el régimen de la responsabilidad estatal desde las dos grandes corrientes - privado y público-: "Quizás ha llegado la hora de hablar de un derecho de la responsabilidad que reúna todos los principios generales, sin perjuicio de los específicos para cada orden normativo", p. 80.

17 Juan Carlos Cassagne, Los principios que fundamentan la responsabilidad extracontractual del Estado y el Alcance de la Reparación. En Responsabilidad del Estado AA.VV. Departamento de Publicaciones. Facultad de Derecho. Universidad de Buenos Aires. Rubinzal Culzoni Editores, 2008, p. 48. También Marienhoff, Miguel "Tratado de Derecho Administrativo", 4a . ed. Abeledo Perrot, Bs.As. 1990, t. I, pp. 152-153. Igualmente, autores de esta rama del derecho, no rechazan el sistema de responsabilidad patrimonial estatal fundado en normas del Código Civil, esto es ubicar la misma en una teoría general de la responsabilidad, y "como una de las fuentes de las obligaciones, de una disposición como la contenida en el art. 1112 del Código Civil, y es por esta razón que su aplicación debe ser "directa".

18 Ob.cit., p. 38. El autor, en páginas siguiente, reafirma su postura al indicar que "debe aceptarse la teoría publicista para resolver el problema de la responsabilidad del Estado. El derecho civil solo se aplica subsidiariamente en el campo del derecho público, que viene a resolver el problema de la responsabilidad dentro del Derecho público y no acudiendo al derecho privado... creemos posible que la jurisprudencia, en lugar de fundarse en disposiciones del Derecho civil que sirven para resolver cuestiones entre particulares, deberá encontrar fundamentos en la Constitución,... para construir toda la teoría de la responsabilidad del Estado", pp. 42-43. 
previsibilidad en una temática que se encontraba sin cobertura legal expresa y sujeta a la interpretación de los jueces. A modo introductorio podemos decir que esta se encarga de la responsabilidad extracontractual del Estado nacional. La regulación de la responsabilidad del Estado suscitó controversias; no todas las opiniones reflejaban alabanzas a la decisión legislativa, por el contrario, se puntualizaban aciertos (Ivanega; Rivero, 2014) ${ }^{19}$ y errores (Gordillo; Bianchi; Mesina de la Estrella; Dalla; Gelli, 2014) ${ }^{20}$.

El Congreso Nacional siguió el texto del proyecto enviado por el Poder Ejecutivo Nacional, modificando - cabe destacarlo- la idea original propiciada por los redactores del Anteproyecto del Código Civil y Comercial Unificado. En dicho anteproyecto, se unificaba el régimen de la responsabilidad civil -sin diferencias entre las personas públicas y privadas-, buscando plasmar una teoría única sobre la institución, fundada -tal idea- en que no deberían existir diferencias sustanciales por el tipo de persona jurídica que ocasiona el hecho o la omisión ${ }^{21}$.

La Comisión de Notables que se encargó de proyectar la norma civil y comercial había establecido la responsabilidad estatal dentro de la "Sección 9" Supuestos especiales de responsabilidad" del Anteproyecto, recogiendo -también corresponde puntualizarlo- la doctrina de la Corte Suprema de Justicia de la Nación ${ }^{22}$. Este apartado del anteproyecto del Código Civil argentino -hoy próximo a regir bajo

19 Mirian M. Ivanega y Ricardo Rivero Ortega en "Acerca de la Ley de Responsabilidad Estatal", Rev. LL del 18/9/2014. En una posición más cercana Pedro Coviello, "Los jueces frente a la Ley de Responsabilidad del Estado", diario ED del 18/9/2014.

20 Agustín Gordillo en su obra Tratado de Derecho Administrativo y Obras Selectas, t. II, "La defensa del usuario y del administrativo". 1ª ed. Fundación de Derecho Administrativo, Bs.As., 2014, Cap. XIX p. 681; Alberto Bianchi en Rev. ED del 18/9/2014, No. 13570; Graciela N. Messina de Estrella Gutiérrez, "El nuevo régimen de Responsabilidad Civil del Estado. Todo un tema en conflicto" la rotularla de "irresponsabilidad del Estado", en Rev. LL del 25/08/14; Dalla Vía, Alberto, "Aspectos constitucionales del Proyecto de Código Civil y Comercial"; María Angélica Gelli, en "Lectura constitucional de la Ley de Responsabilidad del Estado", Rev. LL 2014-E-659.

21 Conforme la redacción efectuada por la "Comisión para la elaboración del proyecto de ley de reforma, actualización y unificación de los códigos Civil y Comercial de la nación", creadas por el Poder Ejecutivo Nacional mediante Decreto N ${ }^{\circ} 191$ BO 28/2/2011. Osvaldo H. Bezzi, aceptó la propuesta de la Comisión originaria, pues consideró útil que la responsabilidad del Estado fuera regulada por el Código Civil y Comercial, con la finalidad de que exista un régimen jurídico uniforme en toda la Nación. En Revista del Colegio de Abogados de La Plata, Ed. Especial. "Unificación y Reforma del Código Civil y Comercial de la Nación”, Año LIV, Nov. 2012, p. 197.

22 La Comisión redactora, al fundar el proyecto expresó "El Estado responde, objetivamente, por los daños causados por el ejercicio irregular de sus funciones, sin que sea necesario identificar a su autor. Se ha utilizado el criterio definido por la Corte Suprema, que consideró que el ejercicio irregular es una violación o anormalidad frente a las obligaciones del servicio regular, entraña una apreciación en concreto que toma en cuenta la naturaleza de la actividad, los medios de que dispone el servicio, el lazo que une a la víctima con el servicio y el grado de previsibilidad del daño (Fallos: 321:1124). Dicho con otras palabras, no se trata de un juicio sobre la conducta de los agentes sino sobre la prestación del servicio y, por ello, la responsabilidad involucrada no es subjetiva, sino objetiva" y, en lo que se refiere a la responsabilidad lícita, se había expresado "se establece que el Estado responde, objetivamente, por los daños derivados de sus actos lícitos que sacrifican intereses de los particulares con desigual reparto de las cargas públicas. La responsabilidad solo comprende el resarcimiento del daño emergente; pero, si es afectada la continuación de una actividad, incluye la compensación del valor de las inversiones no amortizadas, en cuanto hayan sido razonables para su giro. Esta norma sigue criterios de varios fallos de la Corte Suprema". 
la Ley 26994- fue modificado como ya lo manifestáramos por el Poder Ejecutivo Nacional al remitir el "proyecto" de ley de la normativa civil y comercial, excluyendo expresamente del régimen civil lo vinculado a la responsabilidad estatal.

Es así que mediante una ley especial, redactada y sancionada al efecto, el Estado nacional presenta ahora las reglas que regularan la responsabilidad extracontractual del Estado, recogiendo -en general- los principios más sobresalientes que sobre la materia fue elaborando la Corte Suprema de Justicia de la Nación desde el fallo "Devoto" a la fecha.

\section{LA REGULACIÓN DE LA RESPONSABILIDAD ESTATAL: ANÁLISIS DE SU ARTICULADO}

La normativa que merece el presente comentario, se refiere a los daños producidos por la "actividad o inactividad" que proviene del Estado Federal, es decir, la Nación Argentina. Plantea un sistema basado en la idea de la responsabilidad "objetiva" y "directa" desplazando la idea de culpa en la que se funda la generalidad de los ordenamientos privados. Las disposiciones del Código Civil argentino no se aplican para examinar este supuesto especial de responsabilidad, como tampoco se posibilita la aplicación de sanciones pecuniarias disuasivas $\left(\operatorname{art.} 1^{\circ}\right)^{23}$.

\section{a. Su ámbito de aplicación}

La delimitación de la persona pública estatal sobre la que se aplicará la ley es significativa, abarca a las del Estado nacional. Tal limitación es atendible en atención al carácter federal de la organización política que adopta la Argentina (art. $1^{\circ}$ de la Constitución Nacional), donde se admiten la necesaria existencia de las provincias con autonomía plena en lo que respecta a su organización y dictado de normas en el ámbito de su poder (art. $5^{\circ}$ de la Constitución Nacional). A lo que debe admitirse también el municipio, al cual se le ha reconocido un grado significativo de poder para regular en forma independiente-siempre respetando el orden jurídico constitucionalla temática local ${ }^{24}$.

En su oportunidad el profesor Pablo Perrino, al analizar el proyecto que enviara el Poder Ejecutivo -el cual diera origen luego al texto sancionado- postuló que la ley iba a formar parte del acervo de la "denominada legislación federal" y, en

23 "Esta ley rige la responsabilidad del Estado por los daños que su actividad o inactividad les produzca a los bienes o derechos de las personas. La responsabilidad del Estado es objetiva y directa. Las disposiciones del Código Civil no son aplicables a la responsabilidad del Estado de manera directa ni subsidiaria. La sanción pecuniaria disuasiva es improcedente contra el Estado, sus agentes y funcionarios".

24 Art. 123 Constitución de la Nación Argentina. Ver nuestro trabajo sobre "La naturaleza jurídica de las ordenanzas municipales en la provincia de Buenos Aires". Revista La Ley. Buenos Aires, septiembre, 2008. Allí realizamos una síntesis de la situación jurídica del municipio en la Argentina $\mathrm{y}$, en particular, en la provincia de Buenos Aires. 
consecuencia, no era aplicable a los daños provocados por las provincias, la ciudad Autónoma de Buenos Aires ni los municipios, "ya que solo alcanzará" a la "responsabilidad del Estado nacional"25. La ley sancionada se asienta entonces en la idea de que la responsabilidad estatal y de los funcionarios públicos no se encuentra entre las materias "delegadas" a la Nación, lo cual permitirá, por parte de los estados provinciales, dictar su propia regulación.

La doctrina especializada, al delimitar cuáles son las administraciones públicas que quedan incorporadas al régimen federal de responsabilidad estatal, ha postulado que son aquellas que ejercen función administrativa stricto sensu, descartándose la aplicación del régimen jurídico a las personas públicas no estatales o a las sociedades del Estado.

En estos últimos casos, el régimen de responsabilidad será el que proviene de la normativa del derecho privado ${ }^{26}$. Juan Carlos Cassagne al analizar el régimen jurídico de las formas societarias a las que puede echar mano el Estado, entiende que si bien el criterio básico para determinar la condición de persona pública estatal del ente es el de su encuadramiento o pertenencia a la organización administrativa, el mismo se concilia plenamente con el que atribuye carácter comercial a las sociedades anónimas cualquiera fuere su objeto, dado que "de acuerdo con su organización y régimen jurídico privastístico, estas no integran la administración, aun cuando el Estado posea la mayoría total o la casi totalidad de las acciones y el poder decisorio en la entidad"27. En igual sentido, Ismael Mata entiende que las sociedades del Estado no forman parte de la descentralización administrativa porque estas no tiene como límite la personalidad pública estatal, por lo cual "están fuera del sistema orgánico de descentralización" $\mathrm{y}$, tal carácter privado ha quedado confirmado ante la redacción de la ley concursal vigente que permite la declaración en concurso de las sociedades en las que el Estado nacional provincial o municipal es parte. Tal norma "excluye la responsabilidad subsidiaria del Estado" 28 .

25 Responsabilidad por actividad estatal legítima. Proyecto de ley de responsabilidad del Estado y de los agentes públicos. Rev. La Ley 18/6/2014 - Rev. La Ley 2014-C-1078. La ley sancionada expresamente invita a las provincias y la a ciudad autónoma de Buenos Aires a "adherir a los términos de esta ley para la regulación de la responsabilidad estatal en sus ámbitos respectivos", art. 11 .

26 Pablo Perrino, exposición en el curso sobre el análisis de la Ley 26.944 organizado por el Colegio de Abogados de La Plata, Bs.As., Argentina, 28/4/15.

27 Juan Carlos Cassagne, en su trabajo en la Revista La Ley había indicado el autor que los recaudos que deben concurrir para asignarle carácter estatal a una persona jurídica pública, debían ser que la "entidad sea creada por el Estado", que "pertenezca a los cuadros de la administración pública conforme a las normas vigentes sobre organización administrativa" y que "el Estado ejerza un control de tipo administrativo y contable sobre la entidad". De tal forma "quedarían comprendidas dentro del concepto de persona jurídica pública estatal tanto las entidades autárquicas y empresas del Estado regladas por la Ley 13.653, como las entidades descentralizadas sujetas a un régimen jurídico especial que no responden a un tipo genérico determinado", en T. 143 p. 1172, en particular pp. 1176 y 1177.

28 En la obra colectiva "Cuestiones de Acto Administrativo, Reglamentos y otras fuentes del derecho administrativo", Revista RAP, octubre 2009, p. 35. 
Desde otra mirada, se reivindica la aplicación del régimen del derecho público a tales organizaciones adoptadas por el Estado para llevar adelante determinados fines que se definen como estatale ${ }^{29}$ correspondiendo, en consecuencia, recurrirse a los principios del derecho administrativo cuando en las relaciones que entablen tales entidades no se encuentre una solución en su ordenamiento especial; de tal forma deberá acudirse a la analogía con la legislación administrativa.

Bajo esta último planteo resultaría viable someter a las sociedades del Estado nacional al régimen de responsabilidad regulado en la Ley 26.944, solución que también ha sido aceptada en el ámbito del derecho español al analizar la posibilidad de la responsabilidad patrimonial por los daños causados por las sociedades mercantiles cuyo capital pertenece íntegra o parcialmente a una administración pública ${ }^{30}$.

\section{b. La aplicación excepcional de las normas del Código Civil argentino a los casos de responsabilidad estatal}

En este aspecto, existe una contradicción entre las reglas insertas en el Código y aquellas que establece la Ley 26.944, pues esta última establece que Las disposiciones

29 Barra, Rodolfo. "Acerca de la naturaleza jurídica de las sociedades de Estado”, ED. 67-601. En tal trabajo afirma el autor, si bien al analizar el texto de la ley de sociedades del Estado $\mathrm{N}^{\circ} 20705$, "no tenemos dudas al afirmar que las sociedades del Estado son personas de derecho público, regidas por el derecho administrativo y solo subsidiariamente por normas privativas... esta solución se ajusta adecuadamente a las características que la ley... le confiere al ente por ella creado, a la vez que protege debidamente los intereses estatales y privados".

30 De Ahumada Ramos, al detenerse sobre el tema destaca que la "personificación jurídica comporta que los actos que puedan realizar una sociedad mercantil pública solo se imputarán a ella misma, salvo que una norma o un acto de Administración o del Organismo público que ostente su titularidad disponga expresamente que la actuación como tal se imputará a la Administración u Organismo titular de la sociedad". Y al explicar la procedencia de imputar a las Administraciones públicas territoriales la responsabilidad patrimonial de los daños causados por las sociedades mercantiles cuyo capital pertenezca en todo o en parte a la Administración, la solución dependerá en que "la Administración tenga o no un control efectivo sobre la sociedad de que se trate", vinculando tal control jurídicoformal en "la mayor o menor participación accionarial pública", en este andarivel de pensamiento, estima viable la responsabilidad patrimonial solidaria de las Administración pública por los daños extracontractuales que puedan derivarse de la actuación de las sociedades mercantiles cuyo capital le pertenezca íntegramente a la Administración, sin "que pueda establecerse ninguna distinción en función del tipo de actividad que desarrollen las diversas sociedades". En definitiva, la imputación por los daños causados viene "exigida por la imperiosa necesidad de proteger a los sujetos lesionados". "La responsabilidad patrimonial de las administraciones públicas", Ec. Thomson Reuters, 3ra edición, Aranzadi, Navarra- España, 2009, pág. 456/463. De igual forma, para aquellas sociedades donde existe participación de la Administración, si ésta última retuviera el control de la gestión de la sociedad no habría posibilidad de limitar la responsabilidad patrimonial de la Administración, pág. 467. En otro extremo, Manuel Rebollo Puig, al estudiar el régimen de reclamación de la indemnización, explica que "la responsabilidad de las entidades instrumentales con personificación de Derecho privado, incluso ante daños ocasionados en la realización de actividades de servicios públicos, será competente la jurisdicción civil sin que haya que seguir previamente ni el procedimiento administrativo...Aunque sean propiedad de una Administración y mero instrumento de ella, no son Administraciones públicas, por lo no procede la aplicación de las reglas procedimentales de responsabilidad...", en la obra colectiva "La responsabilidad patrimonial de la administración pública", Dir. Tomas Quintana, Tirant lo blanc, Valencia, 2009, $T^{\circ}$ 1, pág. 95/96. 


\section{del Código Civil no son aplicables a la responsabilidad del Estado de manera directa} ni subsidiaria (3er. apartado del artículo $1^{\circ}$ ).

Una hermenéutica más integral del ordenamiento jurídico, nos lleva a postular que aquello que el legislador limitó es la aplicación de las disposiciones del "título"-como dice el Código- vinculado a la "responsabilidad" y, no "todas" las disposiciones del Código, ello porque de tal forma se imposibilitaría, en caso de ausencia de regulación en la Ley de Responsabilidad del Estado, recurrir a determinados institutos que, consagrados en la norma civil, resultan de aplicación a distintas ramas del derecho por formar parte de una teoría general de la ciencia jurídica (v. gr. enriquecimiento sin causa, buena fe, entre otras).

El Alto Tribunal de la Nación, al evaluar la aplicación de los principios de la legislación de fondo en cuestiones de índole administrativa, ha manifestado que aquellos resultan aplicables, "siempre que la solución no esté prevista en el ordenamiento jurídico específico y en tanto aquellos principios y reglas resulten compatibles con el régimen jurídico estructurado por las normas especiales"31.

\section{c. Los eximentes de responsabilidad}

También la legislación federal en comentario ha previsto, de manera general, aquellas circunstancias o hechos que "eximen" de responsabilidad al Estado. Se receptan aquí los supuestos de "casos fortuitos o fuerza mayor" - salvo que sean asumidos por el Estado expresamente por ley especial- y también limita su responsabilidad cuando "el daño se produjo por el hecho de la víctima"32 o "de un tercero" por quien el Estado no debe responder (art. $2^{\circ}$ de la ley). Tales eximentes ya eran pregonados en distintos precedentes jurisprudenciales con anterioridad destacando que verificados los supuestos de caso fortuito o la actitud asumida por la víctima con relación al daño la obligación de responder por parte del Estado desaparecía o se relativizaba, debiendo en cada caso cotejar la incidencia de estos en la ruptura del nexo causal.

Al detenerse en su aplicación la doctrina afirmaba que "no se excluye la responsabilidad estatal en los casos en que el daño haya sido ocasionado no solo por la actividad de la administración, sino también por el hecho de un tercero, o la acción de la propia víctima o un supuesto de caso fortuito. En tales casos, corresponde exonerar parcialmente a la administración de su responsabilidad y hacerla responder

31 Fallos 335:1089. Recientemente ha expresado el Tribunal que resulta pertinente recurrir a los principios de leyes análogas, cuando la norma especial no contiene la solución del caso, "toda vez que la regla de interpretación prevista en el art 16 del Código Civil excede los límites del ámbito del derecho privado, los trasciende y se proyecta como un principio general, vigente en todo el orden jurídico interno", en CSJ 510/2011 (47-G) Gómez, Orlando Mario el Estado Nacional - Ministerio de Justicia - Policía Federal Argentina si Personal Militar y Civil de las FF. AA. y de Seg”, sentencia del 27 de noviembre de 2014.

32 Adviértase que no se utiliza como criterio de exclusión de la responsabilidad la "culpa" de la víctima, sino que se habla de "hecho". 
proporcionalmente a su participación en el evento dañoso"33. En este punto, como en la mayoría de los casos, será el juez quien resolverá lo más justo de acuerdo con las circunstancias fácticas que se verifiquen, entendiendo que aquellas reglas de interpretación que cuentan con suficiente aprobación jurisprudencial pueden servir de base para arribar a una solución equilibrada.

\section{d. La naturaleza objetiva y directa de la responsabilidad del Estado}

La ley reconoce, de manera general, que la responsabilidad patrimonial de la administración, es "objetiva" y "directa", características estas que concuerdan con la calificación forjada mayoritariamente a nivel doctrinario y jurisprudencial en nuestro país.

La calificación de "objetiva" y "directa" que estableció el legislador a la responsabilidad patrimonial del Estado en el ámbito del derecho federal (ya fuera que provenga de actividades o inactividades ilegitimas o legítimas, de cualquiera de sus órganos o entes en tanto importen el ejercicio de función administrativa y produzcan un daño cierto) se convierte en una pauta de interpretación en los distintos supuestos en los cuales deba aplicarse la legislación en estudio.

\section{1) La responsabilidad objetiva del Estado como regla}

Mertehikian sostiene que "la jurisprudencia de la Corte ha ido consolidando el criterio de la imputación objetiva y directa de la responsabilidad extracontractual del Estado, a través de la caracterización de la "falta de servicio" como un criterio objetivo y de la aplicación de la "teoría del órgano", como factor de atribución de las conductas (hechos, actos u omisiones) de sus agentes a la estructura estatal que integran, por formar parte de ella como un todo inescindible y cuyo hito culminante en el desarrollo de esa consolidación jurisprudencial se señala que se produjo en la causa "Vadell" 34 .

La responsabilidad objetiva, alejando la noción de un actuar culposo para que nazca la obligación de indemnizar, también ha sido una posición que se había aceptado en otros ordenamientos jurídicos extranjeros, tal el caso de España ${ }^{35}$ donde

33 Pablo Perrino, Los factores de atribución de la responsabilidad extracontractual del Estado por su actividad ilícita. En Responsabilidad del Estado y del Funcionario Público. Ed. Ciencias de la Administración, División Estudios Administrativos, 2001, p. 62.

34 En sentido concordante, Juan Carlos Cassagne, "Los casos...”, ob.cit., p. 523. Colautti afirma que "la idea de que para que hubiera derecho al resarcimiento era menester la existencia de culpa por parte de los agentes se fue desdibujando paulatinamente en la jurisprudencia hasta llegar al criterio de la responsabilidad directa y objetiva", en "Responsabilidad del Estado....", ob. cit., p. 61.

35 Al comentar el régimen de responsabilidad del sistema español, Ramón Parada, esgrime el siguiente razonamiento que nos parece interesante compartir, "La idea de la innecesaridad del elemento de la culpabilidad... responde a la construcción legal española de la responsabilidad administrativa fundada en el dato objetivo de la lesión y en la indiferencia hacia la concurrencia de culpa o dolo del funcionario o persona alguna, como exige para la responsabilidad entre particulares el artículo 1902 del Código Civil”. En Derecho Administrativo, t. I, "parte general”. Editorial Marcial Pons, 1998 , p. 679. 
el artículo 106 de la Constitución española establece que "los particulares en los términos establecidos por la Ley, tendrán derecho a ser indemnizados por toda lesión que sufran en sus bienes y derechos, salvo en los casos de fuerza mayor, siempre que la lesión sea consecuencia del funcionamiento de los servicios públicos"36.

De acuerdo con la directiva legal hoy vigente en nuestro país, para que surja la responsabilidad patrimonial del Estado Federal, no es preciso que concurran ni se demuestre culpa, negligencia o dolo de sus agentes o funcionarios. La necesidad de calificar o encontrar una conducta culposa no es una obligación que deba acreditarse para quien demande al Estado, sí que el daño alegado derive de "su actividad o inactividad".

No obstante, la literalidad de la norma en comentario, entendemos que la obligación de responder fundada en la teoría de raigambre francesa, "falta de servicio" 37 y de tal forma la objetividad en el factor de atribución para responsabilizar al Estado debe ser analizada en cada caso como también las consecuencias que una aplicación desnuda de sentido y análisis puede ocasionar a este Estado, evitando convertir la teoría como un justificativo para hacer de la administración -o su patrimonio- un seguro colectivo ${ }^{38}$.

36 Parada, entiende que sobre tal reconocimiento expreso "la responsabilidad pasa a reposar de este modo sobre un principio abstracto de garantía de los patrimonios, dejando de ser una sanción personal por un comportamiento inadecuado para convertirse en un mecanismo objetivo de reparación, que se pone en funcionamiento solo si, y en la medida en que, se ha producido una lesión patrimonial... esto significa que nuestra fórmula legal engloba tanto los supuestos de responsabilidad por falta de servicio, funcionamiento anormal, como todos los supuestos de responsabilidad sin falta del Derecho francés..." ob. cit., p. 680. Un estudio acabado del régimen actual de la responsabilidad estatal en el derecho español puede verse en "La responsabilidad patrimonial de las administraciones públicas. Elementos estructurales: lesión de derechos y nexo causal entre la lesión y el funcionamiento de los servicios públicos". Francisco Javier Ahumada Ramos. 3a. ed. 2009. Editorial Thomson Reuters y en la obra colectiva: La responsabilidad patrimonial de la Administración Publica. Estudio general y ámbitos sectoriales. Editorial Tirant Lo Blanch. 2009, ts. I y II.

37 Pablo Perrino, La responsabilidad extracontractual del Estado en el derecho argentino, de la conferencia pronunciada en las Jornadas de Derecho Administrativo en los países del Mercosur, Facultad Austral Bs.As. 10, 11 y 12 de septiembre de 1997. En el ámbito español, se ha sostenido que "la naturaleza objetiva del instituto resarcitorio no implica que, en orden a decidir si procede declarar una concreta responsabilidad de la administración, sea siempre irrelevante la diligencia o negligencia con que aquella haya actuado, o que no sea nunca necesaria la demostración de la existencia de culpa en la conducta de los agentes... son numerosos los casos en que para que se pueda establecer el carácter antijurídico - objetivo- del daño (es decir, determinar que se ha producido una efectiva lesión del derecho de un particular imputable a la administración), será absolutamente necesario demostrar, o al menos tener por cierta, la existencia de una conducta negligente de la administración. Es lo que ocurre, por ejemplo,... en un gran número de supuestos de responsabilidad por omisión" (F.J. de Ahumada Ramos, 2009, pp. 66-67).

38 Ovaldo Otheguy analizando la responsabilidad del Estado y del agente público exponía "en la actualidad, tratándose de faltas de servicios, el damnificado no puede demandar al agente; este no es responsable. Tratándose de una "falta personal" en ejercicio u ocasión de la función o fuera del servicio, pero con alguna vinculación con el mismo... el damnificado puede optar por demandar a la administración o al agente, o demandarlos en forma conjunta. Si se trata de una falta puramente personal, carente de toda vinculación con el servicio, el damnificado no podrá demandar a la Administración... Como consecuencia del sistema de acumulación, si la administración es 
Desde esta perspectiva, Perrino admite que, «si bien no es preciso demostrar la culpa del funcionario en los términos del derecho civil ello no significa que con la mera acreditación del daño y del nexo de causalidad se es merecedor de una reparación económica, porque es preciso demostrar el anormal o irregular funcionamiento de la Administración, para cuya determinación deberá realizarse sobre la base de una apreciación en concreto que tome en cuenta la naturaleza de la actividad, los medios de que dispone la administración, el lazo que une a la víctima con el servicio y el grado de previsibilidad del daño ${ }^{39}$.

Graciela Reiriz, al detenerse en el estudio de tal factor de atribución brinda una interpretación de acuerdo con un equilibrio de los intereses en juego en todo juicio indemnizatorio. Indica que la falta de servicio es siempre subjetiva aunque con distinta naturaleza que la culpa o el dolo del derecho civil, porque no es necesaria la individualización del autor material del daño, sino que es el servicio en su totalidad el que funcionando irregularmente, produce el daño. De tal forma, puntualiza Reirez "es un daño con falta del agente causal"

condenada por una "falta personal" del agente, puede accionar contra él ejerciendo la acción de repetición o de regreso". Ver Responsabilidad del Estado y del agente público: falta de servicio y falta personal. Para Perrino, en Responsabilidad del Estado. No obstante lo que refleja el autor, lo cierto es que pocas demandas se intentaban contra los funcionarios, frente a la naturaleza objetiva de la responsabilidad estatal que brindaba mayor seguridad de resarcimiento para la víctima del daño. Otheguy reconoce, al comenzar su trabajo, que de la experiencia jurídica acumulada en los fallos del Tribunal de Cuentas - cuando este funcionaba en la órbita nacional- surge "un dato que tiene cierta constancia: que en algunas ocasiones el agente conductor de vehículos que pudo haber dado lugar un juicio de daños y perjuicios y a una condena contra el Estado por embestir dentro de la apariencia de sus funciones con un vehículo estatal a un vehículo de un administrado... no es condenado en el juicio administrativo de responsabilidad patrimonial llevado a cabo ante el Tribunal de Cuentas en el que se persigue el recupero de lo pagado", p. 281. También Carlos Colautti afirma que la recepción de la teoría de la "responsabilidad objetiva... significó un cambio en el concepto de la responsabilidad de los empleados y funcionarios que en esta tesis... prácticamente se diluye", ob. cit., pp. 56-57. En sentido concordante, ver Miguel A Marafuschi, "Formas y órganos de control sobre la administración pública en la Provincia de Buenos Aires. En Control de la Administración Pública. Editorial RAP, 2002, pp. 39-49, en particular p. 42.

39 Perrino, ob. cit., p. 790 citando en esta postura la sentencia recaída en la causa "Zacarías, Claudio H. c/ Provincia de Córdoba y otros" Sentencia del 28/4/98 publicada en Rev. La Ley, 1998, -C-317.

40 "Responsabilidad del Estado". En El derecho administrativo, hoy. Editorial Ciencias de la Administración, Bs. As., 1996, p. 226, citado por Mertehikian, ob. cit., p. 70. La autora citada, destaca que "el otro sistema es el de la Responsabilidad del Estado sin falta con un factor de atribución objetiva. Y eso fundamentalmente se ha aplicado, en nuestro país, para la responsabilidad del Estado por su actuación lícita, con fundamento directo en normas de la Constitución (arts. 16, 17 y 19), en la Ley de Expropiaciones y, en los últimos tiempos también en el art. 18 de la Ley 19.549”. ob. cit., p. 227. Juan Carlos Cassagne, si bien recuerda la posición de la profesora Reiriz, rechaza la posibilidad de hablar de culpa en la acción del agente público, pues el factor de atribución no es este sino "la configuración de un incumplimiento irregular o funcionamiento defectuoso del servicio, lo cual excluye la voluntad culpable del funcionario causante del daño", agrega el destacado profesor que "por ello no creemos que, en tales supuestos, quepa hablar de una culpa objetivada, por cuanto se trata de conceptos inconciliables habida cuenta de que la falta de servicio se configura por un factor de atribución no subjetivo, que difiere de la culpa en que pueda haber incurrido el funcionario o empleado de la administración y se apoya en la circunstancia objetiva de que el servicio no funciona, o funciona mal, o en forma tardia”. En Los casos "Devoto”... ob. cit., p. 526. 
La teoría receptada en la normativa argentina ya había tenido recepción en España donde su ordenamiento jurídico la recogió, pero en la actualidad -cabe puntualizarlo- tal factor de atribución ha sido puesto en crisis por un conjunto de autores del derecho administrativo, quienes al analizar profundamente el régimen jurídico y sus consecuencias, han puesto reparos a una irradiación absoluta de la teoría para todos los supuestos de responsabilidad ${ }^{41}$.

Hemos pensado ${ }^{42}$ que tal análisis debía ser efectuado también para evitar que el Estado sea colocado como el único e irremediable asegurador de todas las desdichas que sufren los habitantes.

\section{2) La imputación directa: la teoría organicista como fundamento de la imputación}

Examinado lo referente al carácter objetivo de la responsabilidad extracontractual por su actividad o inactividad dañosa, corresponde detenernos en el otro carácter ya apuntado, esto es la imputación "directa" al Estado, basada fundamentalmente en la teoría del órgano, la cual logró brindar una respuesta final y más afín, sobre cómo debía entenderse la relación que vincula al funcionario con la persona jurídica pública en la que desarrolla sus tareas $\mathrm{y}$, ocasionalmente, produce daños.

Toda conducta que la persona física (agente público) realice aparentemente dentro de esas atribuciones será imputada a la persona jurídica a la cual el órgano pertenezca $^{43}$.

41 Oriol Mir Puigpelat. La responsabilidad patrimonial de la administración. Hacía un nuevo sistema. Editorial Civitas, $1^{\text {a }}$. ed. 2002. Con anterioridad, su trabajo: La responsabilidad patrimonial de la administración sanitaria. Organización, imputación y causalidad. Madrid: Civitas, 2000. En similar sentido, Pantaleón Prieto, Fernando. Los anteojos del civilista: hacia una revisión del régimen de responsabilidad patrimonial de las administraciones públicas. En Documentos Administrativos, núm. 237-238, enero-junio de 1994; Nieto, Alejandro. La relación de causalidad en la responsabilidad del Estado. Rev. Española de Administración Pública - REDA, 4, p. 95; Parada Vázquez Ramón. Derecho Administrativo, $t$. I, Parte General, pp. 652 y ss. 12 ed. Madrid: Marcial Pons, 2000.

Una crítica a la postura de los autores citados en esta nota puede constatarse en la obra de Francisco Javier de Ahumada Ramos, donde expone que toda la crítica de Mir PuigPelat "descansa en gravísimos errores conceptuales; lo que lleva a afirmar... que: puede considerarse, sin exagerar, que, mediando relación de causalidad entre la actuación administrativa y el daño sufrido por la víctima, la regla debe ser el nacimiento de la responsabilidad administrativa. Ese modo gravemente erróneo de concebir el instituto resarcimiento, el daño y la relación de causalidad está precisamente en la base del problema denunciado por dicho autor", ob. cit., p. 108. Concluye el autor último citado, "supuesto que la responsabilidad patrimonial objetiva de la administración, no tiene la configuración legal que Mir Puigpelat y la generalidad de la doctrina le otorgan, su propuesta de reforma del sistema legal vigente nos conduciría a una limitación injustificada de las garantías de los ciudadanos en sus relaciones con los poderes públicos", p. 110.

42 Lamoglia Carlos Marcelo, en "Las teorías subjetivas y objetivas en la responsabilidad del Estado por omisión”. RAP 290-diciembre, 2002.

43 Olvaldo Otheguy, ob. cit., p. 286. Al respecto, afirma Agustín Gordillo: "Las entidades estatales manifiestan su actividad y su voluntad a través de sus órganos; el concepto de órgano sirve, pues, para imputar a la entidad de que el órgano forma parte del hecho, la omisión o la manifestación 
En lo que respecta al criterio que debe seguirse para determinar cuando la actuación del agente debe atribuirse al órgano como falta de servicio y cuando importa una "falta personal", Gordillo divide el estudio en "criterio subjetivo" y "objetivo", resultando aplicable para la solución este último, "donde mayor será el número de actos y hechos que se le imputarán al ente del cual el órgano forma parte" ${ }^{" 44}$, siendo también el criterio adoptado por la jurisprudencia en el caso "Vadell", "Hotelera del Río de La Plata SACI"45, "Tejeduría Magallanes" notar el autor, un acto es imputable al Estado (y en su caso lo hace responsable) cuando es ejecutado por el funcionario dentro de sus funciones, sin importar que haya sido hecho o no dentro de sus atribuciones o límites legales específicos. De tal forma, quedando clara la imputación, resultan estériles argumentos de índole administrativo o gestión vinculados a exonerarse de responsabilidad ${ }^{47}$.

Es decir, que aquellos actos personales del funcionario que no acrediten el ejercicio de las tareas a su cargo, dentro de los límites y objeto aparente de aquellas, no podrán ser imputados al órgano y por ende la administración no debe responder. Así, los hechos o conductas realizadas fuera de las llevadas a cabo aparentemente dentro de esas atribuciones serán imputados a la persona física ${ }^{48}$.

\section{e. La responsabilidad del Estado por actividad e inactividad ilegítima}

Corresponde ahora detenernos en los requisitos que deben configurarse para que nazca el deber de responder por el Estado en los casos de actividad ilegitima.

De acuerdo con el texto del artículo $3^{\circ}$ de la Ley:

Son requisitos de la responsabilidad del Estado por actividad e inactividad ilegítima: a) Daño cierto debidamente acreditado por quien lo invoca y mensurable en dinero; b) Imputabilidad material de la actividad o inactividad a un órgano estatal; c) Relación de causalidad adecuada entre la actividad o inactividad del órgano y el daño cuya reparación se persigue;

de voluntad de que se trate. Para algunos autores el órgano es un conjunto de competencias algo así como un "cargo," office, ufficio, Amt, etc.- que será ejercido por una persona física -el funcionario público, agente o "personal" del Estado- que, al actuar dentro de las atribuciones o funciones que le han sido conferidas, produce tal imputación. En este concepto se distingue entre el "órgano jurídico" - el conjunto de competencias-y el "órgano físico", o sea, la persona llamada a ejercer esas competencias". En Tratado de derecho administrativo", t. I, Cap. XII, p. 2. Editorial Fundación Derecho Administrativo.

44 Agustín Gordillo, ob. cit., t. I, p. 4.

45 Fallos 307-I-821.

46 Fallos 312-II-1656.

47 Doctrina caso "Gassull" fallos 160:381. Tomamos la cita de Agustín Gordillo y recordamos lo expresado por Alessi al respecto, afirmamos que "basta que aparezca formalmente presentado como una exteriorización de las funciones propias del cargo...que la determinación volitiva del órgano este dirigida, al menos por lo que resulta de su apariencia exterior, a un fin propio del ente"...que presente un mínimo de reconocibilidad exterior", ob.cit., p. 5.

48 Osvaldo Otheguy, ob.cit. p. 286, citando lo resuelto por la CSJN en la causa "Belleza, Alberto", Fallos 196:101. 
d) Falta de servicio consistente en una actuación u omisión irregular de parte del Estado; la omisión sólo genera responsabilidad cuando se verifica la inobservancia de un deber normativo de actuación expreso y determinado.

\section{1) Daño cierto, acreditado y mensurable en dinero}

El primer recaudo que establece la ley es el de acreditar el "daño" cierto, entendido jurisprudencialmente como "toda lesión a una situación jurídicamente protegida"49, descartándose todo perjuicio o lesión hipotética o conjetural.

Pablo Perrino - al analizar el proyecto de ley- entiende que la regulación alcanza a los daños ocasionados por todos los órganos estatales. Tal afirmación se funda en que

si bien no se realiza una regulación diferenciada de los perjuicios derivados de la actuación de los poderes legislativo y judicial, la referencia que se efectúa en diversos artículos... a la 'responsabilidad del Estado' lato sensu $y$, en lo concerniente al poder judicial, la exclusión establecida en el último párrafo del art. 5 de los daños causados por la actividad judicial legitima el derecho a percibir una indemnización, corroboran lo afirmado ${ }^{50}$.

La apreciación efectuada al analizar el proyecto resulta aplicable al texto sancionado, dado que - en dicho aspecto- no sufrió modificaciones y se condice con la línea jurisprudencial explicitada hasta la fecha.

Sobre este requisito que prevé la ley, corresponde recordar la línea jurisprudencial que al respecto se había forjado con anterioridad a su dictado, entendiendo que aquella ayudará en la interpretación, alcance y delimitación del resarcimiento que se peticione en el marco de la nueva norma. Así, la Corte Suprema de Justicia Nacional ha manifestado que el daño debe ser cierto en su existencia, quedando eliminados del

49 Fallos 318:1531 "Revestek S.A.” citado por Mertehkian, ob. cit., p. 118. En el derecho español describe el ítem en estudio bajo la figura de la "lesión del derecho o injusticia", revistiendo importancia que exista la "lesión de un derecho. En el supuesto de que no haya derecho lesionado podrá haber daño o lesión de un bien, pero no un daño antijurídico”. Francisco Javier de Ahumada Ramos, 2009, p. 162. Sobre la base del mismo ordenamiento, Eva María Menéndez Sebastián afirma que para poder obtener indemnización a través de esta institución lo primero que debe cumplirse es que el daño encaje en el concepto de lesión resarcible, para lo cual deben darse ciertos requisitos y exigencias... a) antijuridicidad de la lesión... la antijuridicidad del daño no se refiere a que derive de una actuación ilegal, es decir, la antijuridicidad no se predica de la actuación que da lugar a la responsabilidad... sino del daño en el sentido de que el administrado no tenga el deber jurídico de soportar tales perjuicios al margen de la legalidad o de la corrección o no de la actuación causante de los mismos... b) daño efectivo, evaluable económicamente e individualizado con relación a una persona o grupo de personas,... daño efectivo y no meras expectativas (Principios de la responsabilidad extracontractual de la administración pública (artículos 139 y 141 LRJPAC)". En La responsabilidad patrimonial de la administración pública..., ob. cit. (Valencia, 2009, t. I, pp. 46 y ss.

50 Pablo Perrino. Responsabilidad por actividad estatal legitima ..., ob. cit., p. 3. 
concepto aquellos perjuicios hipotéticos o potenciales y conjeturales ${ }^{51}$; de tal forma quedan eliminados de la acción indemnizatoria los daños remotos.

La necesidad de acreditar la existencia de un perjuicio concreto no resulta diferente a lo ya prescripto por la CSJN en la causa "Serradilla", donde -como lo recuerda Aberastury- a fin de determinar el alcance de la indemnización se indicó: "la premisa insoslayable en esta materia de que la indemnización de los perjuicios lleva implícita la realidad de estos y su determinación requiere la comprobación judicial de tal extremo, excluyendo de las consecuencias resarcibles a los daños meramente eventuales o conjeturales en la medida en que la indemnización no puede representar un enriquecimiento sin causa para quien invoca ser damnificado"52. El autor recuerda que el Alto Tribunal de la Nación ha requerido la prueba del daño con especial certeza, por lo que yuxtapone el daño con la relación causal (Fallos 332:1367); tal debe ser el criterio de interpretación imperante al momento de examinar la ley en este extremo.

Existe una diferencia marcada en lo que se refiere a la configuración del daño entre la responsabilidad ilegítima y la legitima, toda vez que en esta última el daño además de cierto, debe ser "actual".

La ley en comentario, prescribe, que el daño además de ser indudable y acreditado, debe poder ser "mensurable en dinero". La doctrina ha criticado que el legislador identifique "el daño con su cuantificación en dinero, pues ello significa restringir la amplitud del reconocimiento y, de esta manera, se aleja del criterio de lo que es justo" ${ }^{53}$. No obstante, la jurisprudencia y la doctrina ya contemplaban como necesario para el reconocimiento del resarcimiento que el mismo debía ser "evaluable económicamente y subsistente" ${ }^{54}$.

La omisión del legislador sobre la necesidad de reconocer daños futuros -en tanto sean ciertos y no hipotéticos- puede ser salvada sin problemas sobre la base de entender que la indemnización en la responsabilidad extracontractual por actividad ilegítima debe ser integral, es decir, resarcir plenamente a la víctima por el hecho u omisión irregular. Tal como ya se había expedido la doctrina, no cabe duda que aquella "debe ser integral y comprende todos los perjuicios patrimoniales (daño

51 Fallos 333:1404 donde se indicó que la actora debe haber sufrido un "daño actual y cierto" y, en sentido concordante ver Fallos 311:2863; 313:1.465; 316:1.891; 317:536; A su turno en la Provincia de Buenos Aires, la Suprema Corte de Justicia ha expresado que el daño debe ser efectivo y no eventual, evaluable económicamente, individualizado; evidente consecuencia del accionar del Estado. En caso de un accionar lícito se requiere además especialidad y anormalidad, en este último caso sería que supere los pequeños daños derivados de la convivencia; en DJBA 151. Nro. 12.248.

52 La nueva ley de responsabilidad..., ob. cit., p. 4. Apartado III.2.

53 Aberastury, Pedro. La nueva ley de responsabilidad..., ob. cit., apartado "III.2. Daño cierto".

54 Pablo Esteban Perrino. Los factores de atribución..., ob. cit., p. 60. Similar recaudo en la legislación española (art. 139.2 de la Ley 39/92). 
emergente y lucro cesante), ya sea que deriven de una consecuencia inmediata o mediata, como el daño moral, cuando este fuera procedente" 55 .

Agregamos que jurisprudencialmente se ha reconocido la viabilidad del daño moral a las personas físicas, señalando que este no tiene que necesariamente guardar relación con el daño material, por "no tratarse de un daño accesorio a este" y, además que tal ítem, tiene carácter resarcitorio, vinculado con los "sufrimientos espirituales causados" por el hecho generador de la responsabilidad ${ }^{56}$.

\section{2) Imputabilidad material de la actividad o inactividad}

También se supedita la viabilidad de la acción resarcitoria a la configuración de una imputabilidad de la acción u omisión a un órgano, esto es determinar de dónde provine el hecho dañoso y, como ya lo expusiéramos, la posibilidad de hacer responsable la conducta omisiva o activa de un agente al Estado utilizando la teoría del órgano. La procedencia de la condena estatal queda supeditada, en este aspecto, a la existencia real y concreta de aquella imputabilidad, la misma debe ser "material", con lo cual no puede recurrirse a situaciones potenciales o hipotéticas; la necesidad de imputar al órgano la acción u omisión es imprescindible e inexcusable.

Tal remisión jurídica hoy cuenta con suficiente aceptación por parte de la doctrina y la jurisprudencia del país. Con cita de Llambías ha explicado Mertehikian, "en suma, un acto es imputable al agente cuando se le puede atribuir como obra suya, es decir cuando hay razón suficiente para considerar que el agente es el autor moral de la conducta obrada, como causa inteligente y libre de dicha conducta" ${ }^{57}$. Ello implica no confundir la imputación con el deber de resarcir, esto es la atribución de responsabilidad $^{58}$. La actuación del agente se entenderá como realizada por el propio órgano del cual forma parte, del que no se escinde al ser el integrante del éste último

55 Juan Carlos Cassagne. La responsabilidad extracontractual del Estado en el campo del derecho administrativo. Rev. ED, t. 100, p. 992. En sentido concordante, Oscar Cuadros, opina que "la indemnización plena es una consecuencia directa del carácter siempre ilícito de los actos, hechos u omisiones que daña a terceros...". En Responsabilidad del Estado..., ob. Cit., p. 281.

56 Causa "Rosa, Carlos", Fallos 322:2683 y los citados en dicho precedente; Fallos 333:1404, en la cual se confirmó la sentencia de la cámara que reconoció el ítem en cuestión; Fallos 332:2842 "Gatica, Susana". Particular atención merece lo resuelto por el Alto Tribunal de la Nación en la causa "Mezzadra, Jorge", donde se reconoció el daño moral al actor fundado en el excesivo periodo en que se prolongó un proceso penal para arribar a la sentencia respectiva, sobre la base de sostener que "no caben dudas de que el sometimiento a un proceso de una prolongada e inusitada duración le ha ocasionado al actor, cuanto menos, un padecimiento de esa índole, no ya por haber delinquido sino para saber si ha delinquido o no. En este punto la decisión de la jueza de primera instancia de fijar una indemnización en tal concepto no resulta pasible de tacha alguna", Fallos 334:1302.

57 Ob. Cit., pp. 103-104.

58 Aberastury, Pedro. La nueva ley..., p. 4, anteriormente explica "que cuando se emplea la fórmula imputación directa, por oposición a la indirecta, nos estamos refiriendo a la conducta de la administración que genera un efecto disvalioso, con independencia a la actuación del agente que pudo haber intervenido. Cuando nos referimos a la falta de servicio, en realidad nos estamos refiriendo al factor de atribución, como fundamento o razón que determina la obligación de indemnizar el perjuicio causado". 
y, a su vez formar parte de la propia persona jurídica pública porque también, es parte de él. Puntualiza J.C. Cassagne que, la imputabilidad material del acto o hecho a un órgano del Estado, importa la "imputación objetiva" que prescinde del requisito de la voluntariedad, al contrario de la solución positiva prescripta en el ámbito del Código Civil de Vélez Sarsfield donde ante la falta de discernimiento, intención y libertad se elimina la obligación de responder ${ }^{59}$.

\section{3) Relación de causalidad adecuada entre la actividad o inactividad del órgano y el daño cuya reparación se persigue}

Con tal requisito se busca significar que entre aquella acción u omisión ilícita que se imputa al órgano estatal y el daño cierto que se acredita en la causa, existe una vinculación que hace viable entender que este último debía producirse.

La acreditación de la relación de causalidad reviste trascendencia, ya que su correcta configuración hace al instituto resarcitorio, es por ello que forma parte de uno de los presupuestos básicos de la responsabilidad estatal. Siguiendo el texto de la ley, no verificada la "relación de causalidad adecuada" no puede imputarse a la administración daño o lesión antijurídica alguna, y el resultado de la acción resarcitoria será negativo ${ }^{60}$.

El recaudo en estudio -ya reconocido en los tiempos en que la regulación de la responsabilidad se fundaba en principios y reglas fijadas por la jurisprudenciaimporta la necesidad de hacer un juicio acerca de su probabilidad o previsibilidad en el caso conforme la experiencia y el curso ordinario de las cosas. De tal forma se descartan otras causas que "pueden coadyuvar o agravar tal resultado, pero que, de por sí, no resultan relevantes para alcanzarlo"61.

Se pregona en la doctrina la diferencia entre la relación de causalidad de la imputabilidad, siendo la primera una cuestión de orden físico, material más que

59 En La responsabilidad extracontractual del Estado..., ob. cit., donde concluye "De ese modo, la administración será responsable por los hechos ejecutados por un funcionario público demente cuando su actuación genere una falta de servicio y también lo será aun cuando no pudiera individualizarse el responsable, siempre que pueda atribuirse materialmente el acto o el hecho a la actuación de un órgano del Estado en ejercicio u ocasión de las funciones", p. 990.

60 A su turno, Guido Tawil al examinar la cuestión en el ámbito de la responsabilidad del Estado y de los magistrados y funcionarios judiciales afirmaba que tal como acontece "en los restantes supuestos de responsabilidad, resulta imprescindible, además, la acreditación de una relación o nexo causal directo entre la conducta cuestionada y el perjuicio reparable, de modo tal que conforme al curso natural y común de las cosas, la primera sea idónea para producir el daño cuya reparación se pretende" en la obra La responsabilidad del Estado y de los magistrados y funcionarios judiciales por el mal funcionamiento de la administración de justicia, 2da. ed. Buenos Aires: Depalma, 1993, p. 94.

61 Juan C. Cassagne. Derecho Administrativo, t. I, 8 ${ }^{\text {a }}$ ed. Buenos Aires: Editorial Lexis Nexis, Abeledo-Perrot, 2006, p. 550. El autor destaca que el Superior Tribunal de Justicia de la Nación no ha seguido en este punto una línea constante y uniforme, pues mientras por una parte ha exigido que la conexión causal fuera adecuada (Fallos 315:2319), por otra, consideró que debería ser directa o inmediata (Fallos 12:1656), "conforme a la tendencia de la mayor parte de la jurisprudencia española". 
jurídica, "se trata de saber si un daño es consecuencia de un hecho anterior; mientras que la imputabilidad "es un concepto esencialmente jurídico: se trata de saber si la ley impuesta a una persona la obliga a pagar ciertos daños"62.

En la causalidad, no se trata de la imputabilidad material del hecho o acto administrativo al órgano Estatal sino de determinar si las consecuencias dañosas de ese hecho o acto se siguen necesariamente del mismo u obedecen a otras causas.

El legislador ha escogido formalmente una de las tantas teorías que se han patrocinado para determinar cómo debe configurarse el nexo causal, y de tal forma permitir que se integren el daño y el factor de atribución, en la unidad del acto que es fuente de la obligación de indemnizar. Es un elemento objetivo "porque alude a un vínculo externo entre el daño y el hecho de la persona o de la cosa"63. Las restantes teorías $^{64}$ no lograban dar respuesta clara al problema o intensidad que encierra la "relación de causalidad".

Al confrontar los dos tipos de responsabilidad regulados en la norma -ilegítima y legítima-, en lo que respecta al nexo causal, se advierte que en la legítima se exige que debe ser "directa, inmediata y exclusiva entre la actividad estatal y el daño" (art. $4^{\circ}$ ). La diferencia afirma Aberastury, produce consecuencias en la recepción o concurrencia de las concausas en la producción del daño, concluyendo que en la responsabilidad del Estado por actividad o inactividad ilegítima sí resultarían viable aquellas ${ }^{65}$.

En atención a la redacción y precisión de los requisitos previstos para la procedencia de la responsabilidad del Estado por actividad o inactividad ilegítima,

62 Eduardo Mertehikian, ob. cit., pp. 158-159, quien en su estudio sobre la materia -con anterioridad al dictado de la ley-, al igual que Cassagne, sostiene que para establecer "la relación de causalidad y su consecuencia debe acudirse al Código Civil, el cual, adoptando el criterio de la "causalidad adecuada" distingue entre consecuencias inmediatas, mediatas y casuales y remotas", tal pauta surge del artículo 901 del Código de Vélez, y se halla realizada de acuerdo con un criterio de probabilidad con referencia al acto dañoso, para, seguidamente determinar el propio Código reglas de imputación de dichas consecuencias". El autor concluye que, la regulación civilista puede ser aplicable válidamente, "con las pertinentes modulaciones" a cualquier situación o relación jurídica, incluso al derecho administrativo". Tal postura es la seguida, recuerda Mertehikian, por Bartolomé Fiorini, Adolfo Vázquez, Guido Tawil y Rodolfo Barra.

En este orden, la interpretación efectuada por dicha doctrina puede seguir manteniéndose en el ámbito de la nueva ley, siempre considerando que la remisión o interpretación que se efectúe de las normas civilistas nunca pueden importar una aplicación directa o subsidiaria de dicho ordenamiento, sino solo "analógica".

63 Bustamante Alsina, citado por Aberastury Pedro, ob. cit., p. 5.

64 Entre otras, "equivalencia de las condiciones", de la "causa próxima", de la "causa eficiente y de la causa preponderante".

65 Aberastury, La nueva ley...”, ob. cit., p. 5. El autor, en un trabajo anterior al detenerse en el estudio de la relación de causalidad, afirmaba que "lo cierto es que la cuestión es compleja cuando se analiza la existencia de conductas concurrentes, en la medida que ellas tienen una directa incidencia con el resultado dañoso producido; ya no nos encontraremos con una fractura de la relación causal sino con una interferencia y la consecuencia jurídica de la misma será distinta ante un funcionamiento normal o anormal del servicio", en "La relación de causalidad en la responsabilidad del Estado". En Responsabilidad del Estado. Rubinzal Culzoni Editores, citada, p. 229. 
cabe entender -como se hacía en el anterior régimen jurídico de la responsabilidadque "si bien se requiere que el vínculo causal sea directo, no es preciso que sea exclusivo", con lo cual la responsabilidad del Estado no se excluye en los casos en que el daño sea producto de la actividad de la administración, pero también de la acción de otros sujetos ${ }^{66}$.

\section{4) El requisito de la falta de servicio como una actuación u omisión por parte del Estado}

Por último, a fines de lograr el resarcimiento peticionado, deberá acreditarse la existencia de una "falta de servicio consistente en una actuación u omisión irregular de parte del Estado". Se escoge así el factor de atribución que se forjara en la antigua jurisprudencia de la Corte Suprema de Justicia de la Nación en el caso "Ferrocarril Oeste", toda vez que allí se mencionaba al artículo 1112 del Código Civil que, conforme doctrina autorizada, la norma que consagraba la responsabilidad del Estado por falta de servicio.

Al regular la "falta de servicio" como factor de atribución, la ley nacional ha delimitado de tal forma la posibilidad de invocar otros que oportunamente fueron examinados en el ámbito del derecho administrativo ${ }^{67}$. Cabría preguntarse si, con una interpretación analógica y cuidadosa de la ley civil y, frente a determinados supuestos, no podrían ser aplicables otros factores de atribución, tales como las reglas forjadas con relación a los daños que provienen de las cosas riesgosas -entre otros-. Tal posibilidad ha sido mencionada como una opción sumamente limitada por la doctrina argentina ${ }^{68}$ no obstante, reconocer que la propia Corte Suprema de Justicia Nacional, en algún precedente, había receptado tal factor de atribución en el anterior sistema de la responsabilidad del Estado.

Cassagne puntualiza que el fundamento del factor de atribución recogido en la ley se inscribe en el "principio unitario que rige la responsabilidad estatal que exige "afianzar la justicia" a través de la restitución que procede para restablecer la igualdad alterada por el daño ocasionado al particular por un acto o hecho administrativo"69. Tal como ya lo expusiéramos, la noción de "falta de servicio", fue adoptada por un importante sector de la doctrina nacional y se ha consolidado en la jurisprudencia actual ${ }^{70}$.

66 Pablo Perrino, Los factores de atribución...., ob. cit., p. 62.

67 Pablo Perrino, Los factores...., ob. cit., pp. 72-73.

68 J.C. Cassagne, al detenerse sobre tal opción afirma que "semejante sistema, que mira solo un costado de la responsabilidad como es la reparación de la víctima de los daños, puede ser justo... Pero resulta totalmente inaplicable al derecho público que precisa fundar sus soluciones reparatorias en criterios objetivos vinculados al funcionamiento defectuoso de los servicios públicos...”, para concluir que "la teoría del riesgo,... tendría un campo excepcional de aplicación en el Derecho Administrativo, no en forma directa sino por analogía, debiendo adoptarse a los fines y características propias de la responsabilidad administrativa". En Derecho Administrativo, $8^{\mathrm{a}}$ ed., ob. cit., pp. 551-552.

69 En La responsabilidad extracontractual..., p. 990.

70 Pablo Perrino. Los factores de atribución de la responsabilidad..., ob. cit p. 64. CSJN hace referencia al factor de atribución en Fallos To $334: 1821 ; 332: 2842 ; 332: 548$ 
Al conceptualizar el factor de atribución ahora previsto en el artículo $3^{\circ}$ de la Ley 26.944, cabe recalcar que se lo identifica con un servicio que funciona mal, atrasado o directamente no funciona; es decir, con el incumplimiento de obligaciones preexistentes. La previsión normativa se aplica a distintos supuestos de responsabilidad estatal; esto es que el daño o lesión provenga de la actividad administrativa del Estado nacional o sus entidades descentralizadas, por un mal funcionamiento del servicio de justicia o error judicial, como también de la actividad legislativa -v. gr. Leyes declaradas inconstitucionales-. También se prevé como supuesto de falta de servicio la "omisión", aunque esta solo genera responsabilidad "cuando se verifica la inobservancia de un deber normativo de actuación expreso y determinado"; sobre este último indicaremos que nos parece adecuado que la obligación de responder quede circunscripta al incumplimiento de un "deber legal" expreso.

\section{f. La responsabilidad por omisión}

El legislador también reconoció, ya lo pusimos de relieve al comienzo del trabajo, la posibilidad de entablar una acción indemnizatoria cuando se verifican daños producidos como consecuencia de la inactividad de la administración. En efecto, al regular la responsabilidad por actuación "ilícita" señala que "la omisión solo genera responsabilidad cuando se verifica la inobservancia de un deber normativo de actuación expreso y determinado".

El problema que encierra este tipo de responsabilidad es sumamente sensible, dado que no cualquier inactividad o falta de cumplimiento de determinados fines o cometidos a cargo del Estado pueden generar el derecho a un resarcimiento a favor de los particulares. Como lo sostuvo la doctrina especializada "el Estado no se puede transformar en una suerte de caja aseguradora de todos los riesgos que enfrentan los ciudadanos por la circunstancia de vivir en comunidad medianamente organizadas"71.

Antes de la ley, al igual que con los restantes aspectos de la responsabilidad estatal no existía una norma expresa que regulara la "omisión" estatal y sus consecuencias. La opción de aplicar las reglas del Código Civil que rigió la actividad privada en Argentina -hasta comienzos del mes de agosto del 2015- en forma analógica era planteada como viable $\mathrm{y}$, en dicho ordenamiento jurídico se encontraban dos posibilidades que brindaban elementos para su reconocimiento; aquella que prescribía la necesidad de que la inactividad solo podía generar responsabilidad cuando se hubiera incumplido una "disposición de la ley" que así la impusiera (Art. 1074 C.C. $)^{72}$. Otra posibilidad era examinar el supuesto en análisis sobre la base de la "falta de servicio"73 tal como ya se ha referido en el presente trabajo.

71 Juan Carlos Cassagne. Derecho Administrativo. Editorial Lexis Nexis, Abeledo Perrot, 2006, t. I, p. 553.

72 Tal opción era postulada por Miguel S. Marienhoff. En Responsabilidad extracontractual del Estado por las consecuencias de su actitud "omisiva” en el ámbito de Derecho Público. Abeledo Perrot, Bs.As. 1996, p. 19. Cabe destacar que se hace referencia al texto del Código Civil del codificador Velez Sarfield. Tal texto se ha modificado por Ley 26.994 que comenzó a regir a partir del $1 / 8 / 15$.

73 Postulada por Juan Carlos Cassagne. Derecho Administrativo..., p. 553. 
Hemos entendido que el análisis de la responsabilidad del Estado debía realizarse sobre la base de una norma -ley o su similar-que estableciera expresa y claramente la obligación legal que se imputa incumplida; el legislador nacional ha seguido en este punto la doctrina elaborada por la Corte Suprema de Justicia Nacional en la causa "Mosca"74, esto es que la responsabilidad por omisión solo será procedente "cuando se verifica la inobservancia de un deber normativo de actuación expreso y determinado". Tal opción ha merecido observaciones de la doctrina especializada, sobre la base de postular una concepción más amplia que permita imputar a los órganos del Estado los daños que provengan del incumplimiento de deberes u obligaciones aun cuando los mismos no se encuentren previstos de manera expresa en la legislación, pero la obligación puede tener cabida o sustento analizando otras fuentes del ordenamiento jurídico, tales como los principios generales del derecho ${ }^{75}$.

\section{g. El régimen de la responsabilidad del Estado por actividad legítima}

Al comenzar el análisis de la ley indicábamos que además de los daños ocasionados por un actuar ilícito, el legislador -recogiendo la práctica jurisprudencial- previó también la responsabilidad del Estado en aquellos casos en los cuales el ejercicio de un derecho genera un daño y debe ser indemnizado. La doctrina nacional ya ha advertido, que tal aspecto de la responsabilidad aparece como excepción, dado que la misma "por el acto lícito no procede como regla"76.

La regla imperante es que el ejercicio regular de un derecho no puede generar el derecho a una indemnización o responsabilidad, pues no puede olvidarse que se encuentra en juego el interés público. Tal como lo enseñaba Agustín Gordillo, en este ámbito la posibilidad de obtener la indemnización viene a partir de las excepciones que la misma jurisprudencia ha planteado.

La obligación de indemnizar por parte del Estado en aquellos supuestos en que su actuación no puede ser rotulada como ilícita, pero es la determinante del daño que sufre el administrado, también se legisló en la ley en estudio, recepcionándose -al igual que lo acontecido con la ilegítima- las directivas y bases que la jurisprudencia

74 Fallos 330:563.

75 Pablo Perrino. La falta de servicio en la ley de responsabilidad del Estado y de los funcionarios y agentes públicos. Revista El Derecho, 31/3/15, en especial pp.4-5. El autor entiende que la expresión "deber normativo", comprende "no solo los impuestos por el ordenamiento jurídico positivo... sino también los que nacen de los principios generales del derecho, los cuales integran, al igual que las normas, el ordenamiento jurídico", rechaza de tal forma una aplicación literal del texto del artículo $3^{\circ}$ inc. d) de la ley entendiendo que su aplicación debe ser adecuadamente interpretada con los criterios de la jurisprudencia que hizo lugar a pretensiones indemnizatorias, aun en casos donde la ley no contenía un deber normativo expreso, pero el mismo se deducía del resto del ordenamiento aplicable. En similar sentido, Fabián Omar Canda. Responsabilidad por omisión en la Ley 26.944. El requisito del incumplimiento de un deber estatal normativo expreso y determinado. Una lectura desde el fallo de la CS “C. de P.”. Revista El Derecho, 30/4/15.

76 Aquiles Mairal. Responsabilidad del Estado por su actividad lícita. En Responsabilidad del Estado. Editorial Rubinzal Culzoni, 2008, p. 142. 
-primordialmente federal- ha forjado sobre tal aspecto de la responsabilidad extracontractual del Estado 77.

Conforme lo establece la ley en su artículo $4^{\circ}$ son requisitos para la configuración de un supuesto de responsabilidad legítima:

b. 1. Daño cierto y actual, debidamente acreditado por quien lo invoca y mensurable en dinero. b. 2. Imputabilidad material de la actividad a un órgano estatal. b. 3. Relación de causalidad directa, inmediata y exclusiva entre la actividad estatal y el daño. b. 4. Ausencia del deber jurídico de soportar el daño b. 5. Sacrificio especial en la persona dañada, diferenciado del que sufre el resto de la comunidad, configurado por la afectación de un derecho adquirido.

Se recoge en el artículo los recaudos que jurisprudencialmente veían delineando por la jurisprudencia nacional.

En lo que se refiere el daño, además de cierto y mensurable en dinero, se establece que el mismo debe ser "actual", de tal forma la configuración de tal requisitos o recaudo legal debe ser "estricto" 78 lo que conlleva la necesidad de una puntual acreditación del mismo, con la prueba respectiva por aquel que se encuentra en mejor posición para arrimar los medios probatorios ${ }^{79}$, debiendo los jueces verificar tal extremo.

También aparece una diferencia en lo que se refiere a la relación de causalidad, toda vez que se exige que la misma debe ser "directa, inmediata y exclusiva" ello encuentra respuesta en el carácter excepcional de la responsabilidad por actividad legítima y, por otra parte, recoge - una vez más- el criterio que a su turno había plasmado la jurisprudencia nacional en la causa "Ledesma" $"$. La ley parte de la base que para responsabilizar al Estado debe probarse que aquel daño es consecuencia directa de éste último y, fundamentalmente, que entre ese perjuicio y el accionar lícito no se interpone ninguna otra circunstancia.

De los restantes recaudos exigidos para habilitar la responsabilidad del fisco por su actividad legítima, cabe detenernos en los vinculados a la existencia de un "sacrificio especial en la persona dañada, diferenciado del que sufre el resto de la comunidad, configurado por la afectación de un derecho adquirido " y la "ausencia de un deber jurídico de soportar el daño"; el primero de ello importa la necesidad de demostrar que el perjuicio (sacrificio) que sufre el peticionante es superior en su intensidad al que debe soportarse como consecuencia de la vida en sociedad. Altamira Gigena recuerda que la teoría del sacrificio especial apareció en Alemania

77 En la causa "Los Pinos" (Fallos 297:161), advierte Mairal, la Corte de Justicia Nacional se logra estabilizar la cuestión, reconociendo -siempre como excepción- la posibilidad de responsabilizar al Estado

78 Así también lo entendió Mairal, ob. cit., p. 144.

79 Ver en este aspecto lo indicado por la CSJN en la causa "Prada", sentencia de 16 de marzo de 1993

80 Fallos 312:2022 
y estableció que en la relación entre el Estado y los súbditos, la actividad estatal podrá producir perjuicios que los ciudadanos debían soportar, ya que ello hacia a la existencia misma del Estado, pero si "ese perjuicio afectaba a un individuo de manera desigual y desproporcionada, produciéndose un daño material se configuraba un sacrificio especial que debía indemnizarse por razones de equidad" ${ }^{\prime 1}$. El fundamento de tal reparación se encuentra en el mismo artículo 16 de la Constitución Nacional que consagra la garantía de igualdad.

Es decir, no alcanza con una lesión económica, si la misma no reviste la calidad de grave; esto es que "el damnificado debe demostrar además que se halla en una situación especial, que su sacrificio lo coloca en una situación de desigualdad tal que permite activar la protección" de la protección que consagra el texto constitucional cuando regula el derecho de igualdad, a lo cual se suma que "el sacrificio haya sido hecho en beneficio de la comunidad" 82 . El perjuicio debe afectar un "derecho adquirido" señala la norma, lo cual importa -para todo peticionante- la acreditación de una situación jurídica protegida por el ordenamiento; sigue el legislador en este aspecto la doctrina judicial de la propia Corte Suprema de Justicia Nacional ${ }^{83}$.

El segundo recaudo que debe probarse, conjuntamente con el primero, también es la consagración de la doctrina judicial forjada en la causa "Columbia"84; la acreditación de este extremo importa deslindar otras situaciones en las cuales los habitantes están obligados a "soportar" el daño que ocasionan determinadas decisiones públicas adoptadas en beneficio de la comunidad, sin derecho, por lo tanto, a recibir una indemnización. Los casos vinculados, entre otros casos, a las limitaciones al dominio privado por razones de interés público es un claro ejemplo de estas últimas.

El límite al quantum de la indemnización en este tipo de responsabilidad estatal ha generado algunas críticas en la doctrina nacional, en atención a que el legislador dispuso una restricción en cuanto a la posibilidad de resarcir en forma amplia y plena los perjuicios ocasionados por un actuar legítimo de los órganos estatales.

El reconocimiento de tal responsabilidad, ya lo señaláramos, es excepcional y, por ello no se reconoce el "lucro cesante"; de tal forma se sigue una línea jurisprudencial ${ }^{85}$ y se abandona otra que, en el último tiempo parecía abrir una nueva etapa al

81 Julio Isidro Altamira Gigena. La nueva ley de responsabilidad del Estado y del funcionario. Intervención en la Academia Nacional de Derechos y Ciencias Sociales de Córdoba. Recuperado de www.acaderc.org.ar/doctrina

82 Doctrina la Corte Suprema de la Nación en las causas "Corporación Inversora Los Pinos", fallo antes citado. Ver Alberto Bianchi. La doctrina del "sacrificio especial" en la responsabilidad del Estado por actividad legislativa. En Responsabilidad del Estado, pp. 391 y ss. Donde el autor señala que tal requisito depende de la "casuística judicial".

83 Altamira Gigena, ob. cit., p. 7 donde señala que tal exigencia la estableció la Corte Suprema en el caso "Revestek S.A." de 1995, Fallos 318:531.

84 Fallos 315:1026.

85 Fallos "Laplacette", Fallos 195:66; "Los Pinos" ya citado y el conocido "Motor Once", Fallos 310:943, donde se recoge el dictamen de la procuradora fiscal ante la CSJN, Graciela Reiriz. 
quantum indemnizatorio ${ }^{86}$. También cabe puntualizar que tal limitación se encuentra prevista en el régimen contractual imperante en el ámbito nacional ${ }^{87}$. Igualmente si se confrontan los precedentes jurisprudenciales recaídos en la extensión de la indemnización, la limitación impuesta merecerá su análisis por los jueces, toda vez que la Corte de Justicia Nacional aun cuando el criterio imperante era restrictivo, igualmente ante las circunstancias de cada caso amplió la base indemnizatoria, pues, como lo recuerda Mairal, "rechazar el lucro cesante implica prácticamente no dar ninguna indemnización" 88 .

Efectuada una primera interpretación que corresponde realizar de la ley, corresponde también recordar que el monto de la indemnización solo comprenderá "el valor objetivo del bien y los daños que sean consecuencia directa e inmediata de la actividad desplegada por la autoridad pública", se aplica aquí el mismo criterio utilizado por el legislador argentino al regular el instituto de la "expropiación"89, que era-asimismo- el que postulaba Miguel Marienhoff $\mathrm{f}^{90}$.

\section{h. La responsabilidad de los funcionarios: culpa o dolo para su procedencia}

La ley se ocupa expresamente de la responsabilidad de los funcionarios públicos que, con su actuar, generen el daño que justifica la acción indemnizatoria. El supuesto que acoge la ley es el actuar u omisión del agente o funcionario público, en el ejercicio de su función, que produce un daño al erario público. De acuerdo con los antecedentes parlamentarios de la norma, la responsabilidad del agente sigue siendo "subjetiva", la norma regula la obligación de reparar al Estado, por parte del funcionario, cuando por su actuar irregular le ocasione un perjuicio, en general porque por dicha actuación el Fisco haya sido condenado a una indemnización ${ }^{91}$.

86 Fallo "El Jacaranda S.A.” del 28/7/05, Rev. La Ley, 2006-A-828.

87 Apartado a) art. 12 Decreto $\mathrm{N}^{\circ}$ 1023/01 B.O. 16/8/01.

88 Ob. cit., p. 147. Ver sobre el tema el fallo "Jucalan Forestal Agropecuaria S.A.”, Fallos, 312:2266.

89 Art. 10 Ley 21.499 B.O. 21/01/77.

90 Marienhoffintrodujo la idea de que los principios de la expropiación se extienden a todos los supuestos de privación patrimonial por razones de interés público. Afirmaba el autor "La expropiación tiene gran amplitud conceptual. Sus principios no sólo comprenden y se aplican al específico acto por el cual el Estado, por causa de utilidad pública calificada por ley y previa indemnización, obtiene que le sea transferido un bien o cosa de un particular, sino que tales principios se extienden y aplican a todos los supuestos de privación de la propiedad privada, o de menoscabo patrimonial, por razones de utilidad o interés público. Esto constituye lo que puede llamarse fuerza expansiva de la noción jurídica de expropiación" (Tratado de Derecho Administrativo, 5a ed. act., t. IV, p. 123. Buenos Aires: Abeledo-Perrot, 1992.

91 Altamira Gigena al detenerse en el análisis del artículo $9^{\circ}$ de la ley plantea que "el funcionario público tiene en materia patrimonial dos clases de responsabilidades: una contractual y la otra extracontractual. La primera es con motivo de los daños y perjuicios que ha ocasionado al Estado. A este tipo de responsabilidad contractual no se refiere el artículo... sino, a la extracontractual y la responsabilidad del funcionario público puede ser como consecuencia de la actividad o de la omisión, siempre y cuando fuese en ejercicio de sus funciones. El artículo exige no solo que la actividad sea realizada de manera irregular sino que además haya incurrido en dolo". La nueva ley de responsabilidad del Estado...., ob. cit., p.13. 
Tal responsabilidad convive con las restantes responsabilidades a las cuales se encuentran sujetos los agentes públicos (disciplinaria y penal) como consecuencia de su ingreso a la administración y la aceptación de distintos deberes y funciones que implican el cargo que desempeñan en el marco de una relación de empleo.

De manera clara, el artículo 9 de la ley establece que

la actividad o inactividad de los funcionarios y agentes públicos en el ejercicio de sus funciones por no cumplir sino de una manera irregular, incurriendo en culpa o dolo, las obligaciones legales que les están impuestas, los hace responsables de los daños que causen.

La norma sujeta entonces el nacimiento de la responsabilidad del funcionario y agentes públicos ${ }^{92}$ a la existencia previa de una relación de empleo público, con un actuar antijurídico o irregular en la función asignada - de acuerdo con la normativa general y particular que regula aquella- y que a su vez haya sido materializado de manera culposa o dolosa. No distingue cuales serían los funcionarios o agentes que pueden ser responsabilizados, y de tal forma podría generarse la responsabilidad sin detenernos en el tipo de vínculo jurídico - contractual o nombramiento- que vincula al empleado con el Estado. Los daños, necesariamente, deben ser cierto y consecuencia del obrar antijurídico que la legislación así rotula.

Los conceptos de culpa o dolo en el actuar del agente importa la intención de generar daño al Fisco o, al menos, no haber adoptado las diligencias propias de un buen empleado. La culpa implica un actuar negligente, imprudente o con cierta impericia. Tales extremos, necesariamente, deberán surgir de la prueba producida al respecto en el procedimiento especial que a sus efectos regula la normativa de empleo $\mathrm{y}$, fundamentalmente, de las obligaciones y deberes que se establezcan en esta.

Consigna la normativa la posibilidad, por parte del Estado, de recuperar aquellas sumas abonadas por el Fisco en virtud de un actuar que luego de determinar ha sido doloso o culposo del empleado que ejecutó u omitió la acción declarada antijurídica. Es difícil de conciliar la posibilidad del recupero fiscal, cuando el agente ha obrado sin incurrir en ninguna falta administrativa o, aun, cuando su actuar pudo generar dudas, terminó siendo sobreseído del sumario o no se aplicó sanción alguna.

Distintas vías se abren para el Estado para llevar adelante la recuperación de las sumas abonadas, debiendo previamente determinarse estas y el porcentaje o grado de responsabilidad que se le asigne al agente público. Entre aquellas pueden

92 La doctrina argentina ha indicado que los empleados y funcionarios públicos son aquellos que llevan adelante un trabajo o función específica del Estado, conf. Miguel S. Marienhoff, Tratado de Derecho Administrativo, Buenos Aires, 1970, Tomo III.B, pág.19; en igual sentido Bartolomé Fiorini, Derecho Administrativo, T I pág. 584. No obstante, cabe señalar, citando a Agustín Gordillo, que ello no significa, sin embargo, que el régimen jurídico aplicable sea exactamente el mismo en todos los casos; por el contrario, existen muchas diferencias entre los distintos agentes de la administración, derivadas de que no todos aquellos están comprendidos en el régimen básico general" (Tratado de Derecho Administrativo, Bs.As, Tomo II, pag. 12/13). 
mencionarse la vía judicial y la administrativa; en el caso de esta última el agente debe continuar prestando servicios en el ámbito estatal.

\section{i. Aplicación supletoria al régimen contractual}

El plexo normativo también resulta aplicable a las relaciones contractuales en las que el Estado forma parte, de manera "supletoria" (art. 10). Tal solución no es forzada, si se recuerda que el Decreto $\mathrm{N}^{\circ} 1023 / 01$, destinado a regular la contratación pública en el ámbito nacional, postula la publicación de dicha área. La regla es que "la celebración, ejecución y rescisión de un contrato con el Estado se rige por el derecho administrativo" 93 .

La pauta legal demuestra la decisión del legislador de alejar el análisis de los conflictos contractuales en los que el Estado forme parte, la mirada del derecho privado, al cual solo podrá recurrirse cuando en el ordenamiento jurídico público no se encuentre la solución respectiva, utilizando una interpretación analógica.

\section{j. La responsabilidad de los concesionarios o contratistas de los servicios públicos}

Tal como sucede en la mayoría de los países, el Estado necesita de los particulares para llevar adelante los cometidos o fines públicos asignados por el ordenamiento jurídico. En particular ello se verifica con mayor claridad en el ámbito contractual, donde los administrados colaboran de forma regular y continúa en el quehacer público llevando adelante obras públicas, servicios públicos o proveyendo de insumos necesarios para el normal desarrollo de las actividades a cargo de la administración.

En este contexto, la ley ha venido a dar respuesta a los posibles daños que se ocasionen en el marco de los contratos de servicios, disponiendo que

el Estado no debe responder, ni aun en forma subsidiaria, por los perjuicios ocasionados por los concesionarios o contratistas de los servicios públicos a los cuales se les atribuya o encomiende un cometido estatal, cuando la acción u omisión sea imputable a la función encomendada.

La directiva legal no se aparta de la postura doctrinaria ${ }^{94}$ forjada al respecto cada vez que se examinaba la responsabilidad que le podía caber al Estado como titular

93 Artículo $1^{\circ}$ del Decreto que dispone “Toda contratación de la Administración Nacional se presumirá de índole administrativa, salvo que de ella o de sus antecedentes surja que está sometida a un régimen jurídico de derecho privado". Decreto 1023/01. B.O.24/8/2001.

94 Entre otros, Miguel S. Marienhoff. Tratado de derecho administrativo, t. III-B-585, afirmaba que "la explotación del servicio público lo hace el concesionario a su propia costa y riesgo... ello significa que toda la responsabilidad que derive de hechos que concreten el ejercicio de la concesión, le corresponde al concesionario... La responsabilidad del concesionario se limita a los daños que causare en ejercicio de la concesión, pero al margen de su texto y contenido", también adopta un criterio restrictivo con relación a la posibilidad de que el Estado se convierta en responsable, Agustín Gordillo, ob. cit., t. 2, Cap. XX, pp. 14-16 y Perrino, Pablo E. La responsabilidad de la Administración por su actividad ilícita. Responsabilidad por falta de servicio. E.D. 185-781 
del servicio, al entenderse que el responsable del hecho dañoso es el concesionario, el cual es ajeno a la función administrativa. La pauta aquí inserta ha de ser considerada, necesariamente, en otros tipos de contratos públicos o privados celebrados por el Estado, cuando se deban resolver conflictos de similares características.

Al detenerse sobre este aspecto de la ley, destaca Agustín Gordillo que

la translación de prestaciones a los concesionarios y licenciatarios del Estado ha importado que sean estos los sujetos pasivos de los reclamos de daños y perjuicios que antes correspondía dirigir al Estado. Hay en ello una distinta percepción social del entorno de la cuestión, pues si el concesionario o licenciatario obra con fines de lucro en una explotación monopólica tiene mayores razones para ser el único responsable de los hechos que realiza ${ }^{95}$.

El autor que hemos citado se interroga sobre la posibilidad de corresponsabilizar a los funcionarios públicos que concedieron la concesión con culpa in eligendo o fallaron en su control con culpa in vigilando, concluyendo que "parece improbable que se declare responsable al Estado por tales comportamientos privados, aun mediando culpa in vigilando o in eligendo» y, por otra parte "aquella responsabilidad del concesionario frente al usuario ha sido considerada de carácter contractual" 96.

\section{k. Los plazos de prescripción previstos en la ley}

Por último, hemos de señalar que el texto legal en examen se detiene en los plazos de prescripción aplicables a las acciones que pueden intentarse en virtud de los daños ocasionados por el Estado.

Así, el artículo 7 prescribe "El plazo para demandar al Estado en los supuestos de responsabilidad extracontractual es de tres (3) años computados a partir de la verificación del daño o desde que la acción de daños esté expedita”. La norma no

95 Ob. cit. p. 15.

96 Una posición que habilita la posibilidad de responsabilizar al Estado en el caso de los concesionarios de servicios públicos, en determinados supuestos, es sostenida por Alfredo Silverio Gusman en Daños causados por los concesionarios ¿Puede el Estado eximirse de responsabilidad. En Rev. $L a$ Ley del 9/2/15. El autor alude a la necesidad de interpretar el artículo 6 de la Ley 26944 con "las garantías constitucionales, armonizándolo con el conjunto del ordenamiento jurídico en plenitud... con esa premisa, creo que bajo ningún razonamiento puede derivarse... una veda rígida hacia el reconocimiento de la responsabilidad del Estado por los perjuicios originados por las acciones $\mathrm{u}$ omisiones de los concesionarios". Concluye entonces que "la recta exégesis que podría derivarse de la norma... es que el Estado concedente ya no es solidariamente responsable con el concesionario por los perjuicios que éste irrogue... a lo sumo lo que viene a suministrar el art. 6 es una excepción a la regla de la responsabilidad objetiva y directa...", pero ello no implica, según el autor, que frente a una falta de servicio en el ejercicio de la "actividad de control o vigilancia" no pueda responsabilizarse al Estado concedente. En una posición similar, puede ubicarse Altamira Gigena, aunque reconociendo que está de acuerdo con la regla inserta en el artículo, pero destaca que "el problema se presenta cuando la empresa concesionaria ha caído en insolvencia y, no obstante ello, continúa prestando el servicio... Si el ejercicio de esa actividad ocasiona daños... En este supuesto hay evidentemente una responsabilidad del ente de Control y, por ello, debe hacerse cargo de la parte de la condena que, debido a la insolvencia de la empresa concesionaria, no se ha podido cumplir". En La nueva ley de responsabilidad...", ob. cit., p. 10. 
sigue las distintas posturas que sobre este aspecto se dieron con anterioridad a la sanción de la ley (5 años, 10 años o 2 años), de igual forma, no se encuentra claramente establecido cuál ha de ser el momento desde que debe computarse el plazo, pues las pautas allí insertas pueden generar incertidumbres en su interpretación.

Similar plazo se establece para el caso en que se intente la acción resarcitoria por parte del Estado frente a los perjuicios ocasionados por los empleados o funcionarios públicos a los que refiere el artículo 9 de la ley. En particular se indica que

La pretensión resarcitoria contra funcionarios y agentes públicos prescribe a los tres (3) años y, la acción de repetición del Estado contra los funcionarios o agentes causantes del daño prescribe a los tres (3) años de la sentencia firme que estableció la indemnización (art. $9^{\circ}$ ).

Tal como señala Altamira Gigena, como debe existir certeza de que el funcionario obró de manera irregular "para ello es necesario que una sentencia judicial así lo diga"97.

\section{A MODO DE CONCLUSIÓN}

La ley en comentario, como lo mencionáramos, consagra una gran parte de los principios que desde la jurisprudencia y la doctrina fueron moldeando la responsabilidad patrimonial del Estado en Argentina. Con sus aciertos y omisiones establece los principales aspectos de la responsabilidad estatal, brindado de manera definitiva, las reglas sobre las cuales las partes en el proceso judicial -y los magistrados- deberán adecuar su actuar. De tal forma, se convierten en una herramienta idónea para una temática que estaba huérfana de un debido encuadre legal, no obstante, la relevancia e incidencia que aquella revestía para los habitantes, como también para el mismo Fisco.

Algunas imprecisiones, y tal vez inadvertencias pueden imputarse en su redacción y articulado, falencias estas que la jurisprudencia u otra ley accesoria completarán, pero tales debilidades no logran quebrantar la relevancia que ha importado, en el ordenamiento jurídico federal, contar con una ley que, de forma conjunta, reconozca la responsabilidad patrimonial del Estado y de los funcionarios públicos.

Tales leyes, a diferencia de aquellas que regulan las relaciones jurídicas insertas en el derecho privado, deben lograr materializar el equilibrio entre el derecho del particular que se encuentra lesionado y el bien común que afecta a la comunidad, quien contribuye al tesoro público para hacer frente a las indemnizaciones que luego fija la justicia y debe pagar el Estado.

97 La nueva ley de responsabilidad..., ob. cit., p.14. 


\section{REFERENCIAS}

Altamira, G. (1973). Responsabilidad del Estado. Bs. As.

Cassagne, J. (1986). Derecho administrativo, t. I, Bs. As.

Cassagne, J. Los principios que fundamentan la responsabilidad extracontractual del Estado y el alcance de la reparación. En Responsabilidad del Estado. AA.VV. Departamento de Publicaciones. Facultad de Derecho. Universidad de Buenos Aires.

Coviello, P. (2014). Los jueces frente a la Ley de Responsabilidad del Estado. Diario ED del 18/9/2014.

Gordillo, A. (2014). Tratado de derecho administrativo y obras selectas, t. II, La defensa del usuario y del administrativo. $1^{\mathrm{a}}$. ed. Fundación de Derecho Administrativo, Bs.As.

Hutchinson, T. Los daños producidos por el Estado. Rev. JUS, 36, 194

Kemelmajer de Carlucci, A. (1982). La responsabilidad del Estado: enfoque jurídicoprivado, AA.VV. La responsabilidad del Estado. UNSTA, Tucumán.

Marienhoff, M. (1997). Tratado de derecho administrativo (6ta ed. Actualizada). Abeledo-Perrot. Bs.As.

Mertehikian, M. (1998). La responsabilidad pública. Análisis de la doctrina y la jurisprudencia de la Corte Suprema. Ed. Ábaco de Rodolfo Depalma.

Mosset, J. (2003). Responsabilidad del Estado y de los funcionarios públicos. Rubinzal Culzoni Editores.

Pablo E. Perrino. La Responsabilidad de la Administración por su actividad ilícita. Revista. ED.

Perrino, P. (2001). Los factores de atribución de la responsabilidad extracontractual del Estado por su actividad ilícita. En Responsabilidad del Estado y del Funcionario Público. Ed. Ciencias de la Administración, División Estudios Administrativos.

Reiriz, M. (1969). La responsabilidad del Estado. Bs.As. 


\section{Responsabilidad Estatal}

Ley 26.944

Supuestos.

Sancionada: 2 de julio de 2014

Promulgada de Hecho: 7 de agosto de 2014

El Senado y Cámara de Diputados de la Nación Argentina reunidos en Congreso, etc. sancionan con fuerza de Ley:

ARTÍCULO $1^{\circ}$ — Esta ley rige la responsabilidad del Estado por los daños que su actividad o inactividad les produzca a los bienes o derechos de las personas.

La responsabilidad del Estado es objetiva y directa.

Las disposiciones del Código Civil no son aplicables a la responsabilidad del Estado de manera directa ni subsidiaria.

La sanción pecuniaria disuasiva es improcedente contra el Estado, sus agentes y funcionarios.

ARTÍCULO $2^{\circ}$ - Se exime de responsabilidad al Estado en los siguientes casos:

a) Por los daños y perjuicios que se deriven de casos fortuitos o fuerza mayor, salvo que sean asumidos por el Estado expresamente por ley especial;

b) Cuando el daño se produjo por el hecho de la víctima o de un tercero por quien el Estado no debe responder.

ARTÍCULO $3^{\circ}$ - Son requisitos de la responsabilidad del Estado por actividad e inactividad ilegítima:

a) Daño cierto debidamente acreditado por quien lo invoca y mensurable en dinero;

b) Imputabilidad material de la actividad o inactividad a un órgano estatal;

c) Relación de causalidad adecuada entre la actividad o inactividad del órgano y el daño cuya reparación se persigue;

d) Falta de servicio consistente en una actuación u omisión irregular de parte del Estado; la omisión sólo genera responsabilidad cuando se verifica la inobservancia de un deber normativo de actuación expreso y determinado.

ARTÍCULO $4^{\circ}$ - Son requisitos de la responsabilidad estatal por actividad legítima:

a) Daño cierto y actual, debidamente acreditado por quien lo invoca y mensurable en dinero;

b) Imputabilidad material de la actividad a un órgano estatal;

c) Relación de causalidad directa, inmediata y exclusiva entre la actividad estatal y el daño; 
d) Ausencia de deber jurídico de soportar el daño;

e) Sacrificio especial en la persona dañada, diferenciado del que sufre el resto de la comunidad, configurado por la afectación de un derecho adquirido.

ARTÍCULO $5^{\circ}$ — La responsabilidad del Estado por actividad legítima es de carácter excepcional. En ningún caso procede la reparación del lucro cesante.

La indemnización de la responsabilidad del Estado por actividad legítima comprende el valor objetivo del bien y los daños que sean consecuencia directa e inmediata de la actividad desplegada por la autoridad pública, sin que se tomen en cuenta circunstancias de carácter personal, valores afectivos ni ganancias hipotéticas.

Los daños causados por la actividad judicial legítima del Estado no generan derecho a indemnización.

ARTÍCULO $6^{\circ}$ - El Estado no debe responder, ni aun en forma subsidiaria, por los perjuicios ocasionados por los concesionarios o contratistas de los servicios públicos a los cuales se les atribuya o encomiende un cometido estatal, cuando la acción u omisión sea imputable a la función encomendada.

ARTÍCULO $7^{\circ}$ - El plazo para demandar al Estado en los supuestos de responsabilidad extracontractual es de tres (3) años computados a partir de la verificación del daño o desde que la acción de daños esté expedita.

ARTÍCULO $8^{\circ}-\mathrm{El}$ interesado puede deducir la acción indemnizatoria juntamente con la de nulidad de actos administrativos de alcance individual o general o la de inconstitucionalidad, o después de finalizado el proceso de anulación o de inconstitucionalidad que le sirve de fundamento.

ARTÍCULO $9^{\circ}$ - La actividad o inactividad de los funcionarios y agentes públicos en el ejercicio de sus funciones por no cumplir sino de una manera irregular, incurriendo en culpa o dolo, las obligaciones legales que les están impuestas, los hace responsables de los daños que causen.

La pretensión resarcitoria contra funcionarios y agentes públicos prescribe a los tres (3) años.

La acción de repetición del Estado contra los funcionarios o agentes causantes del daño prescribe a los tres (3) años de la sentencia firme que estableció la indemnización.

ARTÍCULO 10. — La responsabilidad contractual del Estado se rige por lo dispuesto en las normas específicas. En caso de ausencia de regulación, se aplica esta ley en forma supletoria. 
Las disposiciones de la presente ley no serán aplicadas al Estado en su carácter de empleador.

ARTÍCULO 11. - Invitase a las provincias y a la Ciudad Autónoma de Buenos Aires a adherir a los términos de esta ley para la regulación de la responsabilidad estatal en sus ámbitos respectivos.

ARTÍCULO 12. - Comuníquese al Poder Ejecutivo nacional.

DADA EN LA SALA DE SESIONES DEL CONGRESO ARGENTINO, EN BUENOS AIRES, A LOS DOS DÍAS DEL MES DE JULIO DEL AÑO DOS MIL CATORCE.

— REGISTRADA BAJO EL Nº $26.944-$

Julian A. Domínguez. — Juan H. Estrada. — Lucas Chedrese. — Gerardo Zamora. 